

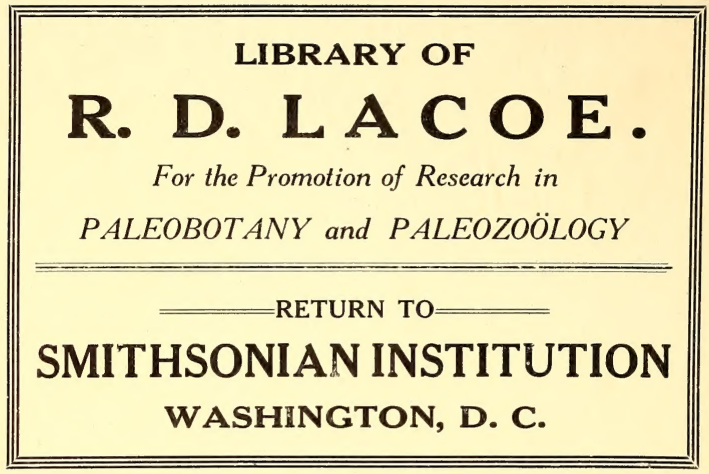












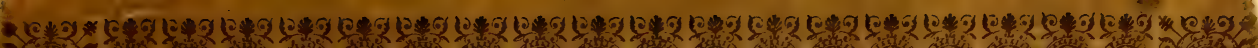

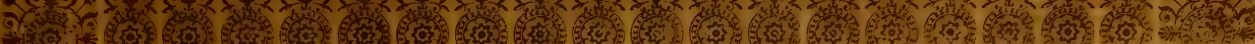
ân ark

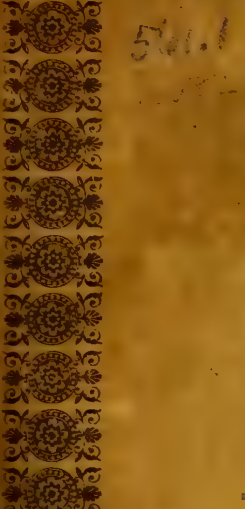

THE

INTERNAL, STRUCTURE

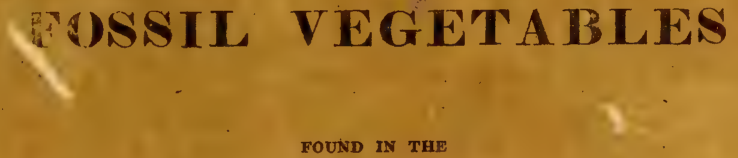

\section{CARBONIFEROUS AND OOLITIC DEPOSITS

\author{
OF GREAT BRITAIN,
}

DESCRIBED AND ILLUSTRATED. (1)<smiles>c1ccccc1</smiles>

a 4015

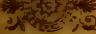
자일 a Yosion

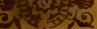
asurye atrisys y.

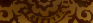
जormate of crons vistos visete unges? sorion $4 \sin \theta$ ar axts arogerie as कर स्तल ox 25 organd sit) erenciso

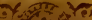
- $2 x+5$ $x$ त्य ationas

BY

HENRY T. M. WITHAM OF LARTINGTON, J. G. S, F. R. S. E., \&ce.

तैfores

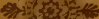
extson

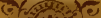
해: (9) a वस Qhis: of ext: : $35=$ ot" nis

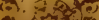
कौ 503 cet

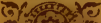
की ख atsis,

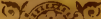
\#t:

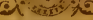
तक जिय कैy elowsic

लैक्यु

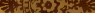

atcisis

(a)

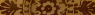

olveriso

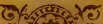

하

(a) of

entasto

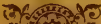

$\Rightarrow$ trots

Qtenesso

(6) एकाइए

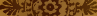

Q)

(ล) 6 काल

औ*

atcicaso

(a) ल्युद

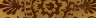

at atosis

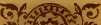

क*t:

Q1 1000

रิ इसंद्नेट

*⿻十⺀㇂

or and

incomis

औ*

7 aros

ثtutos

ch singso

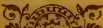

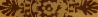

chrosese

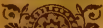

snd 5035

Qreass

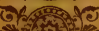

el

करे

औty

Q elentron

तो) कौ⿻

atroris

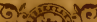
*⿻十 (r) 3 ) ceterisco तx sum

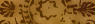

cer $\rightarrow \cdots \times$ (द) लमख 




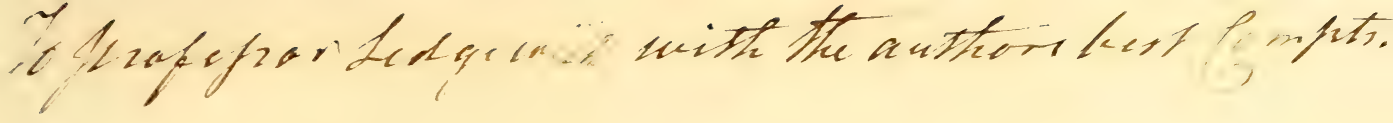

THE

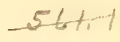

$\because 4822$

INTERNAL STRUCTURE

oF

\section{FOSSIL VEGETABLES}

FOUND IN THE

\section{CARBONIFEROUS AND OOLITIC DEPOSITS OF GREAT BRITAIN,}

DESCRIBED AND ILLUSTRATED.

BY

HENRY T. M. WITHAM OF LARTINGTON, F. G. S., F.R. S. E., \&c.

$=266965$

EDINBURGH :

ADAM \& CHARLES BLACK; AND LONGMAN, REES, ORME, BROWN, GREEN \& LONGMAN, LONDON. 



\section{WILLIAM HUTTON, ESQ.}

\section{My Dear Sir,}

To none can I with more propriety dedicate the following observations on the Structure of Fossil Plants, than to one who has occupied so large a portion of his time in procuring materials, destined to form the foundation of a collection of vegetable remains, which it may reasonably be expected will become one of the most extensive and important in this or any other country. The use which you have already made, in conjunction with our learned friend Professor Lindlex, of the opportunities of examining these objects afforded by your avocations, is sufficiently manifested in the "Fossil Flora of Great Britain," while your unwearied zeal and perseverance have greatly tended to keep in activity any humble powers I may possess. To lend my aid in bringing from their obscure repositories the ancient records of a former state of things, with the view of disclosing the early and mysterious operations of the Great Author of all created things, will ever be to me a source of unalloyed pleasure.

I am,

My Dear Sir,

Most sincerely yours,

\section{HENRY T. M. WITHAM}

EDindergh, lst June 1833. 



\section{INTERNAL STRUCTURE}

\section{OF \\ FOSSIL VEGETABLES.}

\section{INTRODUCTION.}

THE interesting subject of Fossil Vegetation has at length attracted the attention of many of the most ingenious and learned botanists of Europe, whose investigations have thrown considerable light on the nature of those remains of the ancient flora of our globe, which, but a few years ago, seemed destined to remain for ever in obscurity. To me it has always presented peculiar charms, and my efforts to elucidate those objects which fell under my observation have been so far successful, as to induce me to continue them with unremitted diligence. Some of the results of my labours were published in 1831, in a work entitled Observations on Fossil $V$ egetables; others have been communicated to the public in the Transactions of the Royal Society of Edinburgh, and those of the Newcastle Natural History Society. Those which I have since obtained, I have judged it expedient to add to the former, and I now present the whole in connection to my friends, and such persons as may feel an interest in the subject.

My pretensions to botanical knowledge are indeed very limited ; nor do I presume to rank myself among the cultivators of a science to which so many eminent individuals have devoted themselves in this country. The only object I have always steadily kept in view, is to direct their attention to a department of botany which has hitherto been too much neglected; for, although the study of the external forms of the stems, leaves, and fructifica- 
tion, of recent vegetables, has elicited much knowledge respecting the nature of the former, little has been effected by an application to their internal composition, in which decided and characteristic differences are nevertheless to be found.

It is by the recently discovered method of cutting and polishing the stems of fossil plants, that we are enabled to obtain an insight into their structure. I had the pleasure, some years ago, of recommending this method to the York and Newcastle Philosophical and Natural History Societies. It was afterwards fully described in my Observations on Fossil Vegetables; and, in the present work, a detailed account of it will be found in the Appendix.

From the numerous discoveries which have thrown such a volume of new light on the different departments of physical science; from the universal desire of extending our knowledge to a degree of refinement hitherto unattained; from the wide-spread conviction that much may be done in many a yet untrodden waste, I feel confident that the numerous members of the different classes of plants, which beautified the first and succeeding surfaces of our sedimentary deposits, will now obtain that share of attention to which they are so fully entitled.

The conflicting opinions which have been so long entertained by the most learned men, who have directed their attention to this peculiar department, and the many discoveries which have recently been made in the deep and dark depositories of fossil vegetation, proving the existence of tribes of plants before conceived to have been called into existence only at a much more recent period, demand our particular attention. Deeply impressed with this idea, I feel most anxious to convince those who are desirous of cultivating this difficult and much neglected department of science, of the necessity of minute examinations, and repeated comparisons, of the internal structure of fossil stems. In some they will find it retaining all its original beauty; while in others, owing to the different states of decomposition, they will perceive numerous and violent distortions. In many stems they will perceive a mere remnant of structure, the other parts being filled up by extraneous matter, often, however, arranged so beautifully and so symme- 
trically, as at first sight to induce a belief that the original organization remains unimpaired. In such cases, the observer will require to repeat his observations and extend his comparisons, before he can arrive at any safe or satisfactory conclusions. When he has become acquainted with a few general arrangements, by which Nature has characterized the groups into which she has thrown her productions, the observer finds the cloud which before darkened his understanding suddenly dispelled. But this result can only be obtained by the most minute and often repeated microscopic observa. tions and comparisons, not only of fossil plants with each other, but of fossil and recent species together.

My principal object in presenting this work to the public, is to impress upon geologists the advantage of attending more particularly to the intimate organization of fossil plants; and should I succeed in directing their efforts towards the elucidation of this obscure subject, I shall feel a degree of satisfaction which will amply repay my labour. The pleasure which I have derived from my investigations, will be heightened by the reflection, that I have communicated their results to my fellow labourers. At the same time, I trust that the representation of the organic structure of recent and fossil vegetables, which I now offer, will tend to throw some light on the nature of plants hitherto seen but in a very obscure manner.

If the attention lately paid to the study of fossil conchology has been so highly instrumental in clearing up the many doubts respecting the different sedimentary formations; if the works of CUvier, BUCKLAND, and others, have afforded us so many interesting proofs of successive creations, from those of the early inhabitants of the deep, up to the more complicated structure of the bird and the quadruped ;-may we not expect equal pleasure and instruction from an application to the study of these ancient vegetable remains, which, when once properly examined, will facilitate our knowledge of the forms, characters, and qualities peculiar to each epoch, and of the degree of temperature and humidity which must have existed during each period?

These ancient fossils are the medals of our globe, recording changes which it has undergone, and placing before our eyes innumerable specimens 
of Nature's early productions. The study of the wonders of creative power, so profusely scattered wherever we cast our eyes, is calculated to improve the tone of public feeling, by turning into channels of useful inquiry the natural activity of the human mind, to elevate and enlarge our conceptions, and to soften and improve our affections. The study of fossils in particular carries back our thoughts to a time when the British Isles had no place, in their present form, on the map of the world, and when land and sea, mountains and valleys, rivers and plains, continents and oceans, must have been arranged in a way entirely different from what we now behold. While their extreme antiquity commands our veneration, their immense numbers and inconceivable variety and beauty impress us with sentiments of wonder and gratitude, at so great and so marvellous a design.

In the following pages, I propose, 1st, To offer some general remarks on fossil vegetation, from the earliest sedimentary deposits up to the period of the deposition of the chalks, and on the nature and origin of coal ; $2 \mathrm{dly}$, 'To exhibit the distinctive characters of the different tribes of plants in general, and of the Coniferæ in particular; 3dly, To describe the fossil stems retaining organic structure, which have been found in the strata of the Carboniferous series; and to endeavour to illustrate the nature of coal, by presenting the traces of organization, which I have discovered in certain varieties of that substance; 4thly, To describe the structure of certain fossil stems found in the Lias and Oolite ; 5thly, 'To conclude with some general remarks on the plants described, and with an arrangment of them into genera and species, so far as it may be considered practicable. All the objects described will be illustrated by numerous engravings ; and a brief description of the mode of preparing recent and fossil plants for microscopic examination will be given in an appendix.

To Mr Macgillivray, for his unremitted attention and assiduity in the difficult task of executing the beautiful drawings from which the engravings have been made, and for his kind assistance in the minute botanical descriptions of the various plants here presented to the public, I beg to acknowledge my sincere obligation. 


\section{SECTION I.}

REMARKS ON THE VEGETABLE REMAINS OCCURRING IN THE VARIOUS STRATA FROM THE OLD RED SANDSTONE UP TO THE CHALKS, AND ON THE NATURE AND ORIGIN OF COAL.

From investigations made by the most active and experienced botanical geologists, we find reason to conclude that the first appearance of an extensive vegetation occurred in the carboniferous series; and from a recent examination of the mountain-limestone groups and coal-fields of Scotland, and the north of England, we learn that these early vegetable productions, so far from being simple in their structure, as had been supposed, are as complicated as the phanerogamic plants of the present day. This discovery necessarily tends to destroy the once favourite idea, that, from the oldest to the most recent strata, there has been a progressive development of vegetable and animal forms, from the simplest to the most complex.

Such investigations have been rendered easy by our now being able to reduce the hardest and most opaque vegetable fossils hitherto found in these repositories, to a state fitting them for microscopical inspection; so that even by means of a common lens, we can satisfactorily examine the entire organization of these beautiful objects. It is a subject of congratulation to think that, by a comparison of existing vegetable stems, containing woody texture, with the fossil trunks, we may entertain a well-grounded hope, that we shall be able to refer the latter to analogous families or genera of the present vegetation of the globe.

From what has already been done, we are led to believe that the surfaces of the earth, as they successively existed, were adorned in these remote periods, with trees containing woody cellular tissue, differing entirely 
from that presented by the vascular cryptogamic plants, such as the Equisetaceæ, Lycopodiaceæ, and Filices.

Many fossil vegetables having lately been found, particularly in the mountain-limestone series and coal-fields, belonging either to the Coniferæ, or to a family closely allied to them, I am induced to believe that those geologists who maintain that the vascular cryptogamic plants "almost entirely composed the flora of that first period," labour under a misapprehension, entirely owing to the want of means, at the time when they formed such a conclusion, of examining the numerous stems containing remains of original structure, which lay buried in the early sedimentary deposits.

I willingly admit that at that period there existed Equisetaceæ ten feet high, monocotyledonous plants and tree-ferns from fifty to sixty feet high, and arborescent Lycopodiaceæ from sixty to seventy feet high ; but I must contend that there also existed coniferous trees, or such as contained a complicated woody structure, in great abundance, and many of them of a height equal to the loftiest of those just mentioned.

That the preponderance of vascular cryptogamic plants was considerable, I do not wish to question. Many of the shale strata accompanying the combustible beds of the coal-fields, contain innumerable impressions of Filices, Equisetaceæ, and Lycopodiaceæ ; but that the beds, particularly at the bottom of the coal-fields, also contain numberless specimens of gymnospermous phanerogamic plants, or of trees analogous to them, is now established beyond dispute. From the frequent occurrence, therefore, of trees possessing an exogenous structure, I cannot help suspecting the correctness of the assertion, that " the class which almost of itself composed the flora of this period, is that of the vascular cryptogamic plants, and in fact, that of 260 species discovered in this formation, 220 belong to that class."

In a space not exceeding two hundred yards in length, in the quarry of Craigleith near Edinburgh, have been found immense vegetable fossils between forty and fifty feet long, with a diameter of at least, five feet in their lower parts, besides several fragments of trees of similar structure, which, if not Coniferæ, are decidedly as perfect in structure, as will at once be perceived on inspecting the representations of their transverse and lon- 
gitudinal sections, which will be found among the plates of the present work.

At Lennel Braes in Berwickshire, fossil vegetables containing woody cellular structure are to be met with in the greatest abundance. Many of these plants appear to me to differ materially from the true Coniferæ, some containing pith of much greater extent than is to be observed in either the stems or branches of any recent species of pine; and although, in the horizontal section, presenting a regular system of apertures similar to those of pines, yet, in their longitudinal sections, exhibiting appearances differing in several essential respects.

Numerous beautiful remains of stems of similar plants are found at Tweed Mill, on the north bank of that river. At High Heworth, Fellon, Gateshead, and Wideopen, near Newcastle-upon-Tyne, large trunks have also been found. One discovered at the last-named place measured seventy-two feet in length.

At Allen Bank in Berwickshire, we find shale exposed, containing large quantities of stems of fossil trees, many of which seem to have decayed, and to have subsequently been filled with fragments of various vegetables.

To the west of the city of Durham, in a place which I have lately had an opportunity of examining, many plants resembling Coniferæ are found in great profusion, not only in situ, but lying scattered about in the fields, and in the various streams and rills that intersect this portion of the country. The quarry which has afforded the greatest number of these fossils, is situated near Ushaw College, five miles west of Durham, and lies near the Brass Thill seam mentioned by Mr Buddell, in the Transactions for 1831 of the Neweastle Natural History Society.

In the roof of the Bensham coal-seam at Jarrow Colliery, upon the river Tyne, many specimens are found having an appearance very similar to that of the young shoots of the genus Pinus, and which M. A. BrongNIART names Lepidostrobus ornatus, considering them as cones, the scales of which are terminated by rhomboidal disks imbricated from above downwards.

If, therefore, the argument that the combustible beds of our coal-fields 
are composed of vascular cryptogamic plants, rests upon the numerous impressions of the scattered remains of the leaves and stems of that class, why should the many magnificent members of the phanerogamic class be allowed to lie speechless in their early graves, instead of proclaiming the antiquity of their origin, and the usefulness of their order?

It may perhaps be objected, that until lately these phanerogamic plants have never been noticed or discovered in any quantity so low in the series. 'This I admit, but owing to the recent introduction of the method of slicing these opaque bodies, and reducing them to sufficient thinness, we are now enabled to examine their structure as satisfactorily as we could examine that of a recent tree. Before the introduction of this method, owing to the darkness in which they were enveloped, they lay unobserved and neglected; and when one was accidentally discovered, we were unable to assign it a name or a class.

The very effective aid afforded by the microscope in the examination of these fossil stems, has induced me to spend much time in searching for varieties of them in the older deposits; and the success which has attended my efforts in so small a portion of so large a field, and in so short a period, inclines me to believe, that by the united exertions of Foreign and British botanists, the number of gymnospermous phanerogamic plants in these early formations, will ultimately be found greatly to exceed what those who have hitherto written on the subject could in the then existing circumstances expect.

Now, with regard to the number and variety of vascular cryptogamic plants, I cannot help admitting that in many beds of the Newcastle, Durham, and Yorkshire coal-fields, and I doubt not in many others, that the seams are accompanied with various impressions of cryptogamic plants; yet in the Edinburgh or Lothian basins, there are thirty-three beds or seams of coal, and there the impressions of ferns are so rare as to be reckoned curiosities. The same may be said of the other coal-basins in Scotland. Although the leaves and branches of these vasculo-cellular plants, in the above named English coal-fieids, are found scattered about in irregular profusion; yet from the beautiful manner in which they are preserved, we 
find it difficult to trace the operation of any sweeping current. By attending to the manner in which the leaves and branches in recent plantations or forests are found annually at the fall of the leaf, lying indiscriminately in every direction, much of the difficutly arising from the alleged confusion may be got over, as it can be accounted for by the simple operation of violent winds.

If we take it for granted that the coal-seams are formed by the deposition of vegetable matter, produced either on the spot where it is now found, or brought from a distance, we can easily offer an explanation for the differences found to exist between the coal-fields of England above alluded to and the Scotch basins, in regard to the occurrence of fossil vascular cryptogamic plants, and their impressions. In a flat country, like Northumberland, Durham, and Yorkshire, surrounded by mountains of no great elevation, from which a supply of more perfect wood could have been obtained, the vast mass of carbonaceous matter deposited must have resulted from vegetables growing on the spot, and this may have had its origin in a great measure from the vascular cryptogamic plants, which a marshy country, such as it might have been, would have produced in great abundance, and with a luxuriance of which we can now have but little conception, unless we contemplate the profuse vegetation of the Tropics.

The Scotch coal-basins on the contrary, seem to have been formed in large inland lakes or hollows, produced by the expansion of immense bodies of water. In these lakes or hollows, the produce of vast forests, which may have existed in the valleys of the high regions, may have been carried down by eddies and currents. As these trees had grown at great elevations, most of those carried along by the great rivers and their tributary streams may have consisted of Coniferæ, or plants possessing a structure closely allied to that of our present pines.

In coal-fields, in which the carbonaceous strata were formed from such materials, it is not at all surprising that fossils of a vascular cryptogamic character should be considered as rarities; and although, as stated above, many beds of the Newcastle, Durham, and Yorkshire fields are accompanied by varieties of these impressions, yet I believe a considerable number 
even of these beds, with their accompanying shales, possess them sparingly, and some not at all.

If, therefore, we only find these impressions of vascular cryptogamic plants partially distributed, what particular reason have we for maintaining the almost exclusive production of coal from ferns, equisetacex, and other plants of that family, when we find so many phanerogamic plants abounding in these early sedimentary deposits?

If from various specimens of jet and Bovey coal, which are in the possession of many of my friends and in my own, no doubt can be entertained that they were originally stems of plants, possessing a ligneous structure, the concentric rings and fibrous tissue being sufficient evidence to the naked eye that such was the case; and if notwithstanding, from unknown causes, cut them as thin as you like, no true structure can be fairly traced in them; are we on that account warranted to doubt their being dicotyledonous or coniferous, or of a structure allied to the latter?

If, then, many coals, as well as fossil plants from the mountain limestone groups, and true coal-fields, on being cut into thin slices, present a similar appearance, where is the impropriety in assuming the belief that these combustible beds were masses of vascular and cellular cryptogamic plants, mixed with gymnospermous phanerogamic trees, or others of a closely allied structure?

Except in a few instances, I have ineffectually tried, with the aid of the microscope, to obtain some insight into the structure of coal. Owing to its great opacity, which is probably due to mechanical pressure, the action of chemical affinity, and the percolation of acidulous waters, all traces of organization appear to have been obliterated. After frequent trials, however, I have at length been gratified by the discovery of a regular and beautiful texture in the centre of a piece of coal from the mountain limestone group. This in many respects indicates woody tissue, and undoubtedly leaves scope for our most sanguine expectations. By the appearance presented by many varieties of coal, particularly that of Berwickon-Tweed, and that of the Scotch basins, after having been subjected to a certain degree of heat, when it splits and separates in layers almost of 
equal thickness, not unlike the concentric rings of a recent coniferous or dicotyledonous tree, a person might be induced to believe that a portion of these carbonaceous deposits may have indeed been composed of plants belonging to the phanerogamic class.

In the deposits included in the second period of Brongniart, which extends from the magnesian limestone, to the keuper sandstone, and thus includes the red or Exeter conglomerate, the magnesian limestone or zechstein, the new red sandstone or grés bigarrè, the muschelkalk or calcaire conchylien, and the red or variegated marl or keuper, no great variety of fossil vegetable remains have been yet discovered. Those which have occurred, appear to be principally composed of agamic and vascular cryptogamic plants, such as Fuci, Equisetaceæ, Lycopodiaceæ, Filices, \&c.

In the oolitic fields, or the third period of BrongNIART, the vegetation appears to have assumed a more peculiar character. The occurrence in these deposits of so many fragments retaining externally the characters of dicotyledonous woods, naturally induced those who have so long and so assiduously laboured in these repositories, at once to assign to them the peculiar character of possessing those plants. Cycadeæ, Ferns, Equisetaceæ, and Coniferæ, almost entirely compose the flora of this period.

Among the numerous stems found in the various strata on the eastern coast of Yorkshire, and in other parts of England, which I have had the opportunity of examining, I have hitherto met with none presenting the texture of a true dicotyledonous tree. All that have yet been examined, appear to have belonged to the gymnospermous phanerogamic class. When, however, as much time and trouble have been bestowed upon the fossil vegetables of this period, as upon those lower in the series, plants not supposed to have been brought into existence till after the period of the chalk deposits, may perhaps be unexpectedly brought into view.

In these lias and oolitic deposits, we observe, as above stated, vascular cryptogamic and gymnospermous phanerogamic plants deposited together. Now, the more recent vegetable deposits, such as that of Bovey, and the extensive beds on the Rhine, so ably described by Dr Hibbert, are evidently composed chiefly of plants possessing woody texture arranged in con- 
centric layers. The pine forests also at present in existence in many parts of both continents, and on a small scale in this country itself, are accompanied by numerous species of ferns, as well as occasionally Equisetaceæ and Lycopodiaceæ. The latter vegetables in ancient times had been assisted by the heat and moisture which must have invigorated the plants of the islands, from which the early coal-fields were probably formed, when our globe was almost entirely covered by the ocean; and with the gigantic development which they thus acquired, they would have greatly contributed to form those combustible beds, composed of plants belonging to the vascular cryptogamic and phanerogamic classes, having simultaneously perished by some convulsion of nature.

Whilst, therefore, the strength of the argument in favour of the combustible beds of the coal-fields being composed of vascular cryptogamic plants, rests upon the occurrence of the impressions of the latter in great quantity and variety, it appears to me, for the reasons above assigned, that it would not be forcing the argument too far, to claim a large share of the production and consequent composition of these coal-beds, in favour of the gymnospermous phanerogamic class, and of a tribe of vegetables differing little from them in their external appearance, and in their internal texture merely presenting a different disposition of the pores on the walls of the elongated cells constituting the woody fibre, together with frequently the absence of lines marking the union of the woody layers. 


\section{SEC'TION II.}

IEMARKS ON THE DISTINCTIVE CHARACTERS OF THE DIFFERENT TRIBES OF PLANTS IN GENERAL, AND OF THE CONIFERE IN PARTICULAR.

Although the organization of vegetables is sufficiently known, in so far as regards the distinctions by which the larger groups are defined, the more peculiar features which the families and genera present, have not yet received that degree of attention which they require. 'The less perceptible modifications of structure exhibited by species of the same genus are necessarily still less known; and, indeed, when we find that the anatomist is unable to define the species of animals by characters derived from their internal structure, we need not wonder that the botanist should fail in distinguishing those of the vegetable kingdom by similar indications. When I commenced my inquiries into the structure of fossil plants, I was not aware that even the families of recent vegetables had received anatomical investigation, in such a degree at least as to afford any essential aid to the geologist. The assistance which $I$ then received, I acknowledged in the work published by me in 1831 ; but I have since found that the peculiar characters of the different kinds of woody stems have been more minutely given by Dr Kreser, in his Mémoire sur l'Organisation des Plantes, of the information conveyed by which I have therefore availed myself. Labouring under these disadvantages, it will readily be understood how difficult a task it was to me to arrive at any satisfactory results in my investigation of fossil vegetables. I had before me an unknown region, in which I could perceive no footsteps of any previous adventurer; but I hoped at least to open up a path which others might extend. Nor, although I may have erred in confining my investigation to the structure as exhibited by transverse sections alone, have my labours been without benefit. In their Fossil Flora 
of Great Britain, Professor Lindley and Mr Hutwon have shewn that attention to the structure as presented by longitudinal sections, is not less necessary. The extension of my own observations, and the progress of investigation, have enabled me to come to more satisfactory conclusions, which I now proceed to expose.

The vegetable kingdom has been variously arranged. It is not, however, my intention to speak of the differences of opinion among botanists, with respect to the grouping of plants. M. Adolphe Brongniart proposes a distribution of vegetables into six great classes, as follows :

\section{AGAMIC PLANTS.}

These plants have an organization consisting entirely of cellular tissue, or intersecting tubular filaments, are entirely destitute of leaves, and have only, as organs of reproduction, very minute seminula, which appear to be developed without fecundation, and which are contained immediately in membranous conceptacles, similar to the filaments or cellules of the general tissue of the plants.

To this class belong the Algæe, Fungi, and Lichens.

II. CELLULAR CRYPTOGAMIC PLANTS.

The plants of this class have an entirely cellular organization, but they possess leaves having a structure and functions similar to those of the more perfect vegetables. There are sexual organs, and the seminula are contained in conceptacles of a very complex organization.

This class contains the Hepatice and Musci.

\section{VASCULAR CRYPTOGAMIC PLANTS.}

The cellular tissue, which is diversiform, almost always contains distinct vessels, most commonly tracheæ or false tracheæ; the leaves are highly developed, and furnished with cortical pores; the stems are often very large 
and aborescent, bearing some resemblance in their structure to those of the Monocotyledones; and the organs of reproduction appear always to consist of two distinct sexes, which produce seminula contained in conceptacles of complex organization.

This class contains the Equisetacea, Filices, Lycopodiacee, Marsiliacee, and Characece.

\section{GYMNOSPERMOUS PHANEROGAMIC PLANTS.}

To this class belong the very remarkable families of Cycadea and $\mathrm{Co}$ nifere, which cannot be referred to any of the other classes, as their seeds, which are destitute of capsules, receive directly the action of the fecundating substance, and their stems differ in many respects from those of the true Dicotyledones.

V. MONOCOTYLEDONOUS PHANEROGAMIC PLANTS.

In this class, the female organs of reproduction consist of ovules contained in an ovarium, which transmits to them the influence of the fecundating fluid; the embryo has only a single cotyledon; the stem is herbaceous, bulbiform or arborescent, is formed of fibro-vascular fasciculi, is developed by its central part, and is destitute of concentric rings or distinct bark.

To this class belong the Graminea, Juncea, Cyperacec, Liliacea, Palms, \&c.

\section{DICOTYLEDONOUS PHANEROGAMIC PLANTS.}

The female organs of reproduction are of similar structure to those of the last class; the embryo has two cotyledons; the stem is herbaceous or woody, and, in the latter case, is formed of concentric layers, and receives its development from the exterior.

This class contains the greater part of the more ordinary vegetation of the present epoch. 
Of the fossil plants which I have examined with reference to their internal organization, none belong to the first two classes; nor is it likely that the delicate and fragile texture of Algæ and Mosses could be preserved in a petrified state. Those which I shall describe in the present work belong to the third and fourth classes.

At the date of the publication of my Observations on Fossil Vegetables, the attention of geologists had been exclusively confined to the external forms of fossil plants; and these forms, illustrated by reference to living species, and to vegetable anatomy, have afforded characters by which numerous species and genera may be distinguished with accuracy. But the supposed destruction of the internal structure of most fossil plants, and the difficulty of applying the microscope to those which evidently retain it, had prevented our becoming acquainted with the organization of these plants. Many fossil vegetables are converted into a mass of carbonaceous matter; others are filled up with sand and other substances, the external or cortical part alone remaining; but it has been found that not a few retain their original structure, the interstices being filled up by calcareous or siliceous crystallizations. Plants which have been preserved in this manner, frequently disclose their organization as plainly as recent vegetables of like families; but it is more difficult to prepare them for examination.

It will be sufficient here to describe this method very briefly. A thin slice is first cut from the fossil wood, in a direction parallel or perpendicular to the fibres. It is ground flat and polished on one side, which is attached, by means of Canada balsam, to a piece of plate-glass, after which it is ground down to the necessary degree of thinness, and polished. By this means, the internal structure may frequently be as distinctly seen as in the slice of a recent vegetable.

As might be supposed, the remains of the internal organization thus displayed, are frequently distorted and disrupted in various ways, crushed into confused masses, or widely distended and separated. In examining them, therefore, caution is required, lest the regular be confounded with that which has been modified by various causes. The crystallization of the infiltrated substance has operated powerfully, among other causes, in pro- 
ducing these modifications. In general, the calcareous matter has crystallized in divergent prisms, and has thus given rise to a kind of cellular appearance, vèry readily distinguishable from the true, but which a novice might be apt to consider as the regular texture of a cellular or agamic plant; while the siliceous or calcedonic has arranged itself in parallel undulations or series of curves. The appearances produced by the two modes of crystallization are very distinct, insomuch that a person might, in many cases, pronounce with accuracy as to the infiltrated substance, without using any other means of detecting it than ocular inspection.

The regularity of structure displayed by many fossils is truly astonishing. Many of them exhibit an internal texture as perfect as can be obtained from the most delicate sections of a recent plant. The structure thus disclosed often corresponds so precisely with that of recent stems, that one can scarcely hesitate to refer the one and the other to the same genus, although the differences exhibited by recent species of a genus are often so slight, that there appears little hope of our being able to distinguish fossil species by their internal structure, without including other characters.

The remarks which I have now to offer respecting the characters presented by the woody stems of plants, are illustrated by figures, which will be found in the first and second plates.

\section{PLATE I.}

THis Plate contains representations of the internal structure of Recent Plants belonging to the Gymnospermous Phanerogamic, Monocotyledonous Phanerogamic, and Dicotyledonous Phanerogamic Classes, to which we require more particularly to attend, in attempting to determine the organization of the fossil plants to be described. The portions represented are of very thin transverse or horizontal slices, viewed by transmitted light, and magnified about fifty times.

Fig. 1. represents the Monocotyledonous stem, being copied from a por- 
tion of a transverse slice of the stipe of Rhapis fabelliformis, extending from the centre to the circumference. It exhibits a uniform parenchymatous tissue, in which are interspersed bundles of elongated cells, presenting an oval form in their transverse section, and in each of which are seen the apertures of one or more large vessels. There is no pith properly so called, nor does the bark differ materially in structure from the rest of the stem.

Fig. 2. represents the Gymnospermous Phanerogamic stem, and is taken from a portion of a transverse slice of a twig of Pinus balsamea, extending from side to side. This figure exhibits, in the centre, the pith or medulla, composed of large circular or subhexagonal cells, $a$; two annual woody layers or rings, $b, b$; a portion of a third woody layer, $c$; the bark, $d$; and the epidermis, $e$. The dark lines proceeding like radii from the outer margin of the pith to the inner margin of the bark are the medullary rays. The series of small cellules between these rays are formed by the apertures of the elongated cells of the woody tissue; and the irregular apertures in the bark are those of the vasa propria, or vessels containing the resinous secretions of the plant.

Fig. 3. represents the Dicotyledonous Phanerogamic stem, being taken from a portion of a transverse slice of a twig of the Common Ash, Fraxinus excelsior, extending from side to side. It exhibits, in the centre, the pith, $a$, composed of large circular or subhexagonal cells ; four annual woody layers, $b, b, b, b$; the bark in several layers, $c$; and the epidermis, $e$. In these circumstances it resembles Fig. 2, as well as in the medullary rays, the reticular woody tissue, and the vasa propria; but a remarkable difference is presented by the irregular series of large oval apertures, placed in the proximal portion of each woody layer. These are the mouths of the spiral vessels.

The appearances exhibited by the transverse sections of these three tribes of plants are such, that the most careless observer could scarcely confound them; but as a botanical description of all the distinctive peculiarities of their structure forms no part of my plan, I proceed to the detail of those which more directly refer to the object in view; and as the Gymnospermous Phanerogamic plants, or Coniferæ, are those to which our observation is to 
be more particularly directed, I shall, in the first place, mention a few more particulars respecting the appearance which they present in the transverse section.

Fig. 4. American Fir. Shews two complete annual or concentric layers, and portions of other two.

Fig. 5. Scotch Fir, Pinus sylvestris. One concentric layer, with part of other two.

Fig. 6. Norway Fir, Pinus Abies. A concentric layer, and portions of other two.

Now, in these it will be observed, that the apertures of the elongated cells are generally contracted, sometimes entirely closed, towards the outer or distal margin of each annual layer; that the medullary rays are placed at irregular distances, and vary in breadth; and that a few large rounded apertures occur, which are those of vessels or lacunæ. The latter, however, are always few and irregularly scattered in the Coniferæ, and in these respects bear no resemblance to those of the other Dicotyledonous stems.

Fig. 7. Common Yew, Taxus baccata. Part of four layers.

Fig. 8. American Cedar, from Mobile. Part of two layers. In these trees I have not observed any circular apertures.

Fig. 9. Cycas revoluta. Transverse section of a small portion near the centre of a young stem. The cellular tissue is very irregular. A portion of the double circle of fibres is seen, as well as three great spiral vessels, which are filled with cellules, and part of a fasciculus of vessels proceeding to a leaf. The Cycader belong to the same class as the Coniferæ; but I have not succeeded in procuring proper specimens for examination.

Fig. 10. Mahogany, Swietenia Mahogani. The annual layers here are not well defined, a circumstance frequently observable in trees which grow in warm climates.

Fig. 11. Common Oak, Quercus Robur. Part of three layers, which are well defined, and marked towards one of their margins by a denser texture.

Fig. 12. Grey Poplar, Populus canescens. Part of two layers. In this figure the apertures of the cellules are open; but in the others, in 
which, however, the structure is the same, they are partly open, and partly obstructed. There are seen in all, the medullary rays, and the oval apertures of the great and smaller spiral vessels. These three sections are of Dicotyledonous woods, similar to Fig. 3.

Fig. 13. Sandal, or Sander Wood. This approaches in its characters to the last three, but is remarkably compact in its texture, and has its layers united, without any appearance of the lines of separation so apparent in most of the rest.

Fig. 14. Sugar Cane, Saccharum officinarum. Section of a portion of the stem, shewing opaque spots of an oval form, being fasciculi of vessels, generally presenting three apertures of larger spiral vessels; the whole contained in a uniform mass of cellular tissue or parenchyma.

Fig. 15. Section of part of the stem of a species of Calamus, exhibiting a similar arrangement.

\section{PLATE II.}

Transverse sections of Coniferæ, although in themselves affording very decided characters, by which trees of that family may be distinguished from those of any other the structure of which has been examined, are yet insufficient as objects of comparison with those of fossil stems, for establishing a generic identity in the two cases. A segment of the stem or branch of a tree belonging to this family, presents the following structure. There is a central cylinder of medullary cellules, which are of a roundish or irregularly angular form. This cylinder is incased in a tube of woody or fibrous tissue, composed of cellules greatly elongated in a direction parallel to the axis of the stem, and terminated by acute extremities. These cellules are arranged in regular series, radiating from the medulla towards the circumference. Between them are interposed, at irregular intervals, series of cellules, elongated in a direction perpendicular to the axis of the stem, and forming thin plates parallel to the same axis. In a transverse section of the stem, the elongated cellules of this woody tissue are seen to present series of 
squarish or subhexagonal apertures, and the other cellules being seen on the edge of their plane, present the appearance of opaque lines. The latter are the medullary rays, which proceed from the medulla or pith, and run out in the direction of the bark. There may be more cylinders of woody tissue inclosing each other, the last being inclosed by the bark, of which it is unnecessary to describe the structure.

In the transverse section, the medullary rays of the ring next the pith, are usually seen to run out to the bark, through all the successive rings, but the second ring is observed to contain a number of medullary rays originating at its inner margin, and running out through the others. The same is the case with all the successive layers. The only vessels seen in many species are placed on the outer margin of the pith; but in others there are also large vessels or lacunæ scattered in the woody layers.

We must now examine the appearances presented by the elongated cellules of the woody tissue in the longitudinal sections of the stem.

Fig. 1. Exhibits a transverse section of part of a woody layer of a trunk of Pinus sylvestris. Part of the outer margin of the preceding layer is also represented. Several medullary rays are seen.

Fig. 2. Represents a very thin slice, cut parallel to the medullary rays, in the direction of the length of the stem. The form of the elongated cellules is exposed, and between them are seen the intercellular canals. The lines running across the elongated cellules are portions of the medullary rays. On the walls of the cellules are disposed, in a single series, at a greater or less distance from each other, circular substances or vacuities, which some suppose to be glands, and others to be pores. They usually present the appearance of a double circle.

Fig. 3. If we obtain a very thin slice, by cutting parallel to the bark, in the direction of the length of the stem, we observe the same general arrangement as in Fig. 2. Here, however, the medullary rays have been cut across, and present a different appearance. Four of them are seen in the figure. The walls of the elongated cellular tissue are also found to be entirely destitute of pores.

Figs. 4, 5, 6. Represent similar sections of the Spruce Fir. 
Figs. 7, 8, 9. Also represent similar sections of the Weymouth Pine.

On examining other species of Coniferæ, we find the same general appearances, with slight modifications. It is therefore an essential character of these trees, that the walls of the elongated cellules, when viewed on the sides next to the medullary rays, should present a single series of globules or circular pores, and that the other sides of these cellules, or those facing the bark, and the pith should be compact and uniform.

'The Cycadex are said to be the only plants known to resemble the Coniferæ in these respects; but as I have not been able to procure specimens of them for examination, I am unable to say any thing of importance respecting their structure. 


\section{SECTION III.}

DESCRIPTION OF FOSSIL TREES DISCOVERED IN THE STRATA OF THE CARBONIFEROUS SERIES.

I. Fossil vegetables found at lennel braes, near coldstream, on the BANKS OF THE RIVER TWEED, IN BERWICKSHIRE.

IN the neighbourhood of Coldstream, on the banks of the Tweed, numerous fossil vegetables occur imbedded in shale. It has long been disputed to what class of rocks the deposits of this district ought to be referred. Some are of opinion that they are members of the old red sandstone series, while others think that they are to be classed with a much more recent deposit, the new red sandstone. The following facts, which have been observed by my intelligent friend Mr Francis Forster and myself, will, I trust, set that question at rest.

Immediately below the bridge at Coldstream, at its south end, you perceive a bed of shale belonging to the mountain limestone series. It may be seen rising to the north-west, at an angle of about $14^{\circ}$. Above the bridge, on the north side, beds of sandstone, bituminous shale, and ironstone, form the cliff, rising $8^{\circ}$ to the west.

Between the bridge at Coldstream and Lennel Braes, a distance of rather more than two miles, a great variety of shale and grit beds, evidently belonging to the mountain limestone series, may be seen rising to the south and south-south-west, but irregular in their inclinations.

Lennel Braes being exposed to the waters of the Tweed, these ancient fossils are to be obtained there in the greatest abundance. Both banks of the river are occupied by alternating beds of sandstone and shale, from Lennel Braes down to a very fine sandstone cliff, about three fourths of a mile above Sir David MiLnE's house. 
This sandstone has many characteristic marks of the new red sandstone formation; but there is reason to believe that it belongs to the mountain limestone series. It is about forty-five feet in height, and nearly 120 yards in length. It dips at an angle of $9^{\circ}$, in the direction of north $35^{\circ}$ east, and is underlaid at its western point by a bed of shale, containing remains of vegetables, and dipping north $37^{\circ}$ east, at an angle of $16^{\circ}$.

At Tweed Mill, lower down the river, we find an abundant supply of these singular plants.

On the north side of the river, at Twizell grounds, a similar sandstone is quarried. The position of this sandstone is altered near the bank, being bent down towards the river. It dips here $8^{\circ}$ to the north-east, but in the western part of the quarry it appears to take a more regular course, and dips to the south at the rate of $\mathbf{8}^{\circ}$. Farther down the river, a bed of shale is seen abutting against this sandstone, evidently thrown up by a fault. This quarry possesses all the characters of the new red sandstone. There is also a bed of sandstone quarried in the burn side close to Milnegraden. It is of a grey colour, and close-grained, affording a very fine building stone. It dips at an angle of 5 to the south-south-east.

Again, a few hundred yards to the north of Coldstream, is a thick bed of very fine sandstone, belonging to the mountain limestone group, dipping to the south-east. It rests upon a bed of soft bituminous shale, of unknown thickness, and the beds of sandstone are streaked and irregularly marked with the same substance.

It is unnecessary here to describe the various appearances presented in the neighbouring districts, in which shales and sandstones of similar character prevail, all of which lie below the great mountain limestone, as described by me in the Transactions of the Natural History Society of Newcastle-upon-Tyne. I shall therefore proceed to display the internal structure of the fossil stems, which occur so abundantly in these deposits.

Their contorted and flattened shape is worthy of remark. Probably their present forms may have been caused by extreme pressure, when these vegetables were in a state of decomposition. It is impossible to ascertain their height, as they have been fractured and dislocated. The longest stem 
I have been able to obtain, is not much more than four feet, and the lowest part of it is about six feet in circumference.

In Plate III. is represented a transverse section, viewed by reflected light, and diminished one-half, of a portion of one of these fossil vegetables, found in the lowest exposed bed of shale at Lennel Braes, on the Tweed.

These stems, as already mentioned, are generally distorted and flattened. They are invested with a coat of carbonized matter, in all respects resembling the purer kinds of common coal. No two stems or portions of stems, possess the woody appearances in their interior alike, some retaining them in the centre, others having them distributed in various parts. The exterior is irregularly grooved in the longitudinal direction. No indication of branches was observed. The nature of the interior will be best understood by referring to the figure.

Within an external layer of carbonaceous matter $f, f, f$, is exhibited an irregularly oval surface, presenting various modifications of colour and texture.

$\boldsymbol{b}$, Is the centre, converted into calcareous spar, of which substance all the white rays and veins consist.

$a, a, a$, Portions retaining organic texture, and arranged in a radiating manner, from the centre $b$, towards the circumference, but losing themselves in the apparently cellular mass of which the greater portion of the stem is composed.

$c, c, c$, Portions of the same nature as $a, a, a$, dispersed irregularly, and presenting in the transverse section an oval or oblong figure, but running continuously through the mass, in its longitudinal direction.

$d, d, d$, The mass in which the organic portions are imbedded. It consists of crystallizations of calcareous spar, surrounded by carbonaceous and clayey matter, and presents somewhat of a cellular appearance, but is not organic.

$e, e$, Indurated argillaceous matter.

This much is shewn of the external forms and internal arrangement of these remarkable stems, as seen by the naked eye. What the microscope discloses, I now proceed to describe. 
The following is the analysis of a portion of one of these fossils, weighing 20 grains :

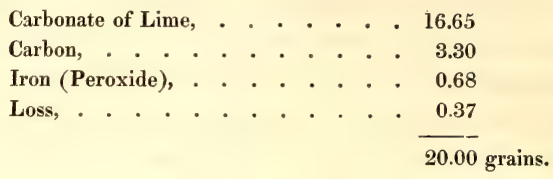

In Plate IV., the organic texture of these trees is exhibited as seen in transverse slices, viewed by transmitted light. Figs. 1. and 2. are of the natural size; Figs, 3, 4, 5, 6, and 7. are magnified in various degrees.

Fig. 1. Transverse section of one of the fragments of a fossil tree found at Lennel Braes, of the natural size, shewing the organic parts $\boldsymbol{a}, \boldsymbol{a}$, imbedded in the apparently cellular mass $b, b, b$, disorganized by crystallizations of calcareous spar. The white lines, longitudinal and transverse, are veins of calcareous spar.

Fig. 2. One of the organic parts, from another portion, represented of the natural size.

Fig. 3. Part of one of these portions of organic texture, magnified about thirty-five times.

Fig. 4. Portion of the same more highly magnified, shewing a regular woody texture, and medullary rays.

Fig. 5. Portion of the apparently cellular part $b, b$, of Fig. 1. magnified. The divergent crystallization of the calcareous spar is here distinctly seen.

Fig. 6. Portion shewing a medullary ray, and the adjacent parts, highly magnified. The former is distinctly seen to be composed of irregular elongated cellules in several series.

Fig. 7. Portion of the same organic texture, shewing part of a small intersecting vein of calcareous spar.

From these figures, it will be seen, that the general arrangement is similar to that of the Coniferæ, as exhibited in Plate I., there being regular series of cellules, forming the woody texture, together with distinct medul- 
lary rays. In these two circumstances, the texture is alike in the fossil plants here represented, and the recent plants; but in the former, there is no appearance of the concentric lines by which the woody layers of the latter are separated.

The portions represented are chiefly calcareous; but in some fragments in which the cavities have been filled with siliceous matter, there is some appearance of these concentric lines. Whether the want of them in the calcareous portion be owing to a more advanced state of decomposition, or to any other cause, must be merely conjectural; and it is not my wish to force the conclusion. In all, however, the resemblance to the Coniferæ is so striking, that unless the longitudinal sections present decided differences, one could hardly hesitate to refer the fossil in question to the Gymnospermous Phanerogamic class.

It is seldom that the central part of these stems is found entire; but in one specimen $I$ have succeeded in detecting it of its natural form. It presents the appearance of a distinct medullary cylinder about two inches in diameter. Externally of the pith is a broad zone of woody tissue, similar to that of the Coniferæ, but with the medullary rays more or less flexuous, which, however, may be owing to distortion produced by various causes.

No recent coniferous plant has a pith approaching in any degree to this magnitude; but whether this circumstance ought to induce us to eject the Lennel Braes fossil from the class in question, seems a little doubtful.

In this fine specimen, I cannot discover any decided traces of vessels, although some of the apertures differ in form from the rest.

The examination of the longitudinal sections may be deferred, owing to the arrangement of the plates, until we have examined the structure of some analogous species.

FOSSII, TREES FOUND IN CRAIGLEITH QUARRY, NEAR EDINBURGH.

In the year 1826, an enormous trunk was exposed in the lowest bed of Craigleith Quarry, near Edinburgh, at a depth of upwards of 136 feet. The 
length of this trunk was 36 feet, and its diameter at the base 3 feet. It lay in a nearly horizontal position, corresponding with that of the stratum of hard white sandstone, in which it was imbedded. Externally, it was marked with irregular longitudinal grooves and prominences, and was encased in a layer of coaly matter, being probably the altered remains of the bark. No branches were observed. Internally, it exhibited in some places an irregular fibrous or fascicular structure, of a dark grey colour, with reticulations of carbonaceous matter. The cracks and fissures were filled with calcareous spar, and the irregular cavities which it presented were lined by crystals of pearl-spar.

An analysis of a portion of this plant afforded the following result;

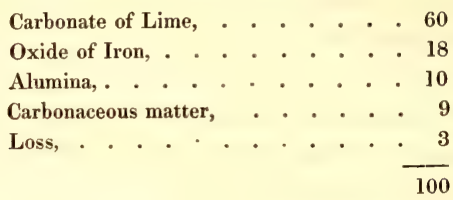

In Plate IV. are seen representations of portions of transverse slices of this stem.

Fig. 8. Portion of the Craigleith tree of 1826, shewing the regular woody texture, separated by medullary rays; magnified about forty-five times.

Fig. 9. Another portion of the same, magnified in the same degree, in which the woody texture and medullary rays are more or less distorted.

Fig. 10. A portion of the same tree, magnified about fifty-five times, very regular in its texture, and shewing a medullary ray irregularly lacerated.

Figs. 11. and 12. Portions of the same, shewing various degrees of separation of the woody texture or induratea or elongated cellules, their walls being very thin in Fig. 11. and very thick in Fig. 12.

The absence of lines of separation of the woody layers, is the only circumstance in which these figures differ from those of transverse sections of 
the recent Coniferæ, Figs. 4, 5, 6, 7, and 8. of Plate I. In every thing else, the accordance is perfect.

In November 1830, a magnificent Fossil stem was discovered in the same quarry, which, in geological position, is situated in the Mountain Limestone group, and lies considerably below the great coal basins of the Lothians. Its elevation above the medium level of the sea, by barometrical measurement, is $\mathbf{7 5}$ feet. In the part of the quarry in which the fossil was situated, the strata inclined to the NNE. 1 foot in $4 \frac{1}{2}$. This part of the quarry assumed a trough-like shape, the one side dipping at an angle of $20^{\circ}$ to the south, and the other at an angle of $20^{\circ}$ to the north. At the bottom of the basin lay the base of this splendid trunk. The general direction of the tree which is represented in Plate $\mathrm{V}_{\text {., was }} 20^{\circ}$ west by north ; and the dips were as follows :-A B. at an angle of $20^{\circ}$; B C $44^{\circ} 5^{\prime}$; C D E $39^{\circ} 35^{\prime}$; F $28^{\circ}$; G $28^{\circ}$.

The length of the stem, from the base to the top, was 47 feet. It presented the appearance of a large branchless trunk, in some parts greatly flattened, so as to form an elliptical section. The diameters were nearly as follows, and will best show the places and proportions of such flattenings :-

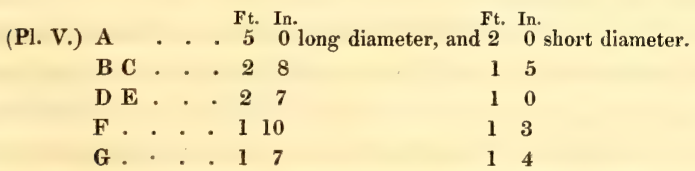

On the edges of the latter diameter it was not more than 7 inches.

From the diameter of the highest part mentioned, it appears quite evident, that many feet of the top part of the stem must have been taken away unobserved ere it attracted the notice of the public, leaving fair ground to conclude, that, when it waved in the winds which whistled through its branches, it stood at least 60 feet in height. Judging from the unworked rock near where the stem lay, the superincumbent mass must have been above $\mathbf{1 0 0}$ feet in depth. The stem tapered gradually, and was marked at 
irregular intervals with a kind of transverse rugæ or irregular prominences. The bark was converted into coal, and presented indistinct longitudinal markings, with very small transverse ridges. At some of the prominences the rugæ were contorted, so as to exhibit the appearances which the bark of some recent trees present, at the coming off of the branches.

That the forms of fossil trees are frequently much altered prior to their consolidation, or during the process of petrifaction, there can be no doubt. The shapes themselves, and the circumstances in which the fossils are discovered, often sufficiently bear evidence to the fact, that pressure and other agents have been at work. But recourse has often been had to this mode of explanation in cases where it could not apply, and when one much more easy was at hand. It is by no means uncommon to find amongst recent trees forms similar to those of fossil plants, which have been ascribed to pressure and other external causes. The flattening of this fossil tree is only similar to what exists in living nature, although, for various reasons, I am unwilling to believe that to be the case in this splendid specimen of primeval vegetation.

The usual way of accounting for such flattenings is by pressure, although, in the present case, where the tree is not parallel to the strata, it is rather difficult to suppose its form to be owing to that cause. The pressure by loose sand, or by sand mixed with water, would act all round the stem, and so would not flatten it; but, if we suppose that the tree, in its recent state, was carried along by a torrent of water and sand, and left sticking, as the latter consolidated, it would afterwards begin to decay, when the hardened strata would necessarily press down upon it, and so produce the flattening; and those parts of the stem which decomposed rapidly, would naturally shew the effect of pressure most,- and such, I believe to have been the case with the stem under consideration.

Several scientific gentlemen having stated as their opinion that this fossil is a Lycopodium, I may here mention the reasons why I have come to a different conclusion. There is no appearance of insertions of leaves on any part of it, nor any markings similar to those of the scales of palms or ferns, or the imbricated leaves of the Lycopodia. Judging from external appear- 
ances alone, the probability is that it is a stem of a Dicotyledonous or Gymnospermous Phanerogamic plant.

Representations of portions of transverse slices of it may be seen in Figs. 1. and 2. of Plate VI. These figures shew it to be similar in all respects to the great trunk found in the same quarry in 1826 .

Fig. 1. exhibits the usual structure of the Coniferæ; but the appearances of the margins of concentric woody layers are very slight, and not such as would induce us to infer with certainty that they actually existed.

Fig. 2. represents a portion, in part of which the texture is destroyed by fissures filled with calcareous spar and carbonaceous matter.

Figs. 3. and 4. represent portions in which the medullary rays and general texture are more perfect.

It has, however, decided medullary rays and woody tissue, and therefore it cannot be a Lycopodium.

It may here be mentioned, that the concentric rings, so very apparent in plants belonging to the Lias and Oolite, are not by any means so conspicuous in those found in the Mountain Limestone series and coal-fields. Yet, from the examination of the few slices of this fine trunk that have been cut, I should be inclined to expect that they may yet be found in some part of it.

The following is the analysis of this fossil tree :-

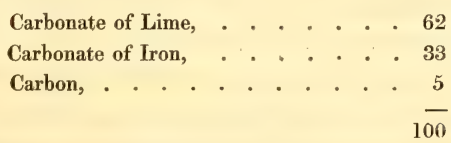

Specific Gravity, 2.87.

A fragment of a third fossil stem with a branch, was found, in 1831, in the same quarry, on its southern side, between the site of the trunk of $\mathbf{1 8 2 6}$ and that of the one last described. It is represented by Fig. I. of Plate V. This fragment and branch were imbedded in one of those indurated parts of the rock, called by the workmen "Kettle-bottoms." The rock being so hard, it became necessary to blast it, which probably detached the branch 
from the fragment of the stem. The latter has been sliced, and shews the concentric rings in a perfection almost approaching to the fossils of the Lias.

Fig. 5. represents a thin transverse slice, viewed by transmitted light, and of the natural size. The pith is seen to be very large, and there are decided indications of five concentric layers.

Fig. 6. represents the pith highly magnified. Besides the large apertures of the circular cells, there are others of much smaller size, presenting somewhat of the appearance of vessels.

Fig. 7. represents a portion of a transverse slice, in which are seen the margin of the pith, several medullary rays proceeding from it, and the ordinary reticulated appearance of the elongated cellules.

Fig. 8. represents the breadth of the two inner woody layers, with part of the third. The lines of separation are distinct; and the medullary rays, together with the series of cellules, are flexuous, probably from accidental distortion.

The texture is much better preserved, in the branch of which the above figures are representations, than in either of the great stems; but in all it is similar.

The analysis of the fragment and branch is as follows:-

$$
\begin{aligned}
& \text { Lime, . . . . . . . } 37.5 \\
& \text { Peroxide of Iron, . . . . . . } 24.2 \\
& \text { Coal, . . . . . . . . . } 38.1 \\
& \overline{99.8}
\end{aligned}
$$

It is singular that the composition of these stems should differ so much from that of the enclosing rock. When we find in beds of sandstone and shale, vegetable trunks transmuted into substances of a similar nature, the presence of the sand or mud, and the decay of the vegetable matter, afford an easy explanation of the manner in which the transmutation has been effected; but when the petrifying substance is different in nature from that forming the matrix of the fossil, difficulties occur. Yet, if we take the whole mass or group of substances constituting a formation, we may find 
means of accounting for the fact. For instance, large fossil trees are found in the mountain limestone groups. In this series, we have abundance of lime, and the reason why the sandstone contains less lime than the fossil, appears to be, that before the strata were consolidated, the sand being more incoherent than the wood, the lime found a more easy passage through it, and was not therefore retained in so great quantity as in the fossil, the vacuities left by the decay of which it gradually filled up.

Dr Gregory, who has been kind enough to examine the Craigleith fossil, has favoured me with the following remarks upon it. "The iron exists in the state of peroxide in the mineral. If reduced to protoxide, it would amount to 21.8 per cent., and the loss would be 2.4 per cent. of which a part is water. The coaly matter is, like ordinary coal, partly volatile, yielding inflammable gas and bituminous matter by heat. The residue is nearly pure charcoal about 14.3 per cent. The mineral contains very minute traces of silica and alumina. The other fragments have a similar composition, only the lime is more abundant, from the presence of some crystals of calcareous spar, which it is impossible to separate completely."

It will be seen afterwards, that the composition of the fossil stems of the coal formation, differs essentially from that of the trunks occurring in this series of rocks, some of the former having as much as 95 per cent. of silica.

Having described the external appearance of the Craigleith trunks, and examined their transverse sections with the microscope, we now proceed to inspect their longitudinal sections.

In Plate VII., are represented thin slices as viewed by the microscope.

Fig. 1. Represents a small portion of a slice cut longitudinally parallel to the medullary rays, taken from the fossil tree of 1826 . The texture of this stem was very much altered and distorted, so that it was difficult to obtain characteristic specimens. In the minute portion represented, as well as in several other specimens, there were seen distinct appearances of elongated cellules similar to those of the Coniferr; but, as is observed in the figure, the walls of these cellules, instead of presenting a single series of separated circular glands or pores, were marked with series of parallel long1- 
tudinal circular or hexagonal apertures. In general, the number of these series seems to be three, sometimes two, and in other instances four or five. Indications of medullary rays occur in these sections, although there happened to be none in the portion figured.

Fig. 2. Is a small portion of a slice cut longitudinally parallel to the bark. Viewed in this direction, the texture is equally confused, the elongated cellules being much distorted. Their walls seem, however, to be continuous, and entirely destitute of markings. A portion of the transverse section of a medullary ray is seen, presenting three irregular rows of cellules.

The great fossil tree found in the same quarry in 1830, retains its structure in a more perfect state, although it also is much disorganized. Two sections of it are represented in Plate VII.

Fig. 3. Is a section similar to Fig. 2, that is, longitudinal and parallel to the bark. The elongated cellules of the woody tissue are distinctly seen, together with two medullary rays, one of which has two, the other three series of cellules. Sometimes, however, four series are observed.

Fig. 4. Represents a longitudinal section, parallel to the medullary rays, and exhibits the elongated cellules in a perfect state of preservation. These cellules are seen covered with series of hexagonal apertures, generally three or two in number, sometimes four. The transverse lines are indications of a medullary ray.

There is nothing in the appearance of the sections of these two great trunks of 1826 and 1830, to indicate that they may be of different species; but it is distinctly seen that they are not Coniferæ, or at least not in all respects similar to the Coniferæ of the present day.

In their transverse sections, the tissue is precisely similar to that of the recent Coniferæ, as represented in Plates I. and II., in respect to the elongated cellules or woody fibres, and the medullary rays; but no decided appearances of concentric circles have been observed. In the longitudinal sections, the two walls of the cells facing the medullary rays, are covered with longitudinal series of hexagonal markings, while the walls next to the medullary rays are destitute of markings, being apparently continuous. 
Messrs Lindley and Hutton, in the first volume of their Fossil Flora, p. 9, Plate II, have described and figured sections of the trunk of 1826. Observing that the structure differs in the respects indicated above from the recent Coniferæ, but acknowledging an affinity to that family, they have referred it to a genus instituted by themselves, under the name of Pinites, and have honoured me by giving it the specific name of Withami. I see no reason for supposing the great tree of 1830 to be of a different species.

The fragment described above as having occurred in the early part of 1831 , is precisely similar in its transverse sections to the two great trunks.

Fig. 5. Represents a longitudinal section of the elongated cellules parallel to the medullary rays; and

Fig. 6. A longitudinal section, in which one of the rays is cut across, and exhibits four series of cellules.

These sections differ in no essential respects from those already presented. It is therefore probable that the fragment of 1831, was a portion of a tree of the same species.

Lastly, the branch which occurred in 1831, and of which transverse sections are given in Plate VI. Figs. 5, 6, 7, and 8, remains to be described.

The authors of the Fossil Flora have described and figured transverse sections of it. Finding the pith to be "four times greater in diameter than the first zone of wood that surrounds it," they have considered this circumstance as affording a specific character. Having seen no longitudinal section, but observing that in the transverse section, the appearance of the tissue is " as nearly as possible that of the tree" of 1826, they have referred it to the same genus, and named it Pinites medullaris.

Fig. 7. Represents a longitudinal section parallel to the medullary rays, in which the tissue is seen to be precisely similar to analogous sections of the two great trunks.

Fig. 8. Represents a longitudinal section parallel to the bark, and is very similar to Fig. 6. of the same plate, which is a section of the fragment of 1831 . 
The only differences to be observed between the texture of the branch in question, and the other fossils of the same quarry, is, that, in the transverse sections, there are distinct traces of concentric lines, and in the sections parallel to the bark, the medullary rays are more numerous, and more uniformly of about four series of cellules. As to the pith, I am unable to say what its size may be in the great trunks. The branch of 1831 is therefore probably of the same species as the rest, although it may be allowed to retain the name imposed upon it, and be considered as a doubtful species, until the examination of the pith of the other fossils decide the question.

We now return to the fossils found at Lennel Braes, on the Tweed, which have been partially described. In addition to the transverse sections of these plants figured in Plate IV, it is necessary to present other two, which will be seen in Plate VII.

Fig. 11. Represents, of the natural size, the pith, as mentioned at p. 27, of extraordinary magnitude, encircled by the woody tissue, in which are seen medullary rays radiating in the usual manner. The central part of the pith is broken up by crystallizations of calcareous spar, and the woody tissue by fissures filled with the same substance. 'This plant is obviously more deserving of the name of medullaris than the Craigleith branch just described.

Fig. 12. Is a highly magnified portion of the same section, not far from the margin of the pith. Two medullary rays are seen, together with a few apertures of the elongated cellules. It seems somewhat remarkable that the tissue intervening between these cellules, and even the interior of the cellules themselves, in some parts, are filled with very minute reticulations. In other respects, however, the tissue resembles that of the Coniferæ, and of the Craigleith fossils.

Fig. 9. Is a longitudinal section parallel to the medullary rays. In this direction, the tissue is much broken up and confused, so that only in one minute space $I$ have been able to detect its real nature. The elongated cells are there seen, as represented to contain two series of roundish 
or subhexagonal markings, similar to those of Figs. 1, 4, 5, and 7 of the same plate; but separated from each other to a considerable distance. In the same figure (9.) are dark spots resembling the single pores of the recent Coniferæ; but, in general, the walls of the cellules are confusedly marked, as if the reticulations had been obliterated by decomposition or crystallization.

Fig. 10. Is a longitudinal section parallel to the bark, in which is represented a medullary ray of four or five series of cellules, and several of the cellules of the woody fibre.

Excepting in the circumstances of having the medullary rays usually somewhat broader, and the areolæ of the cellules separated, this plant is similar to those of Craigleith. These circumstances, however, indicate a generic difference, but as they exist in greater perfection in other fossils, the remarks which I have to offer respecting it, may be deferred until we have examined the tissue of another tree from a different locality, of the same deposit, which appears to me to belong to the same species. I shall merely state here that I propose giving to the Lennel Braes' plants the name of Pitus antiqua.

FOSSIL PLANTS FOUND AT TWEED MILL, ON THE BANKS OF THE RIVER TWEED, IN BERWICKSHIRE.

THE remains of ancient vegetation which are found at Tweed Mill, about a mile below Lennel Braes, resemble those of the latter locality in their external appearance; and it is probable that they belong to the same deposit, or even the same stratum. I have obtained several very beautiful sections of portions of these plants, which are represented in Plate VIII.

Fig. 1. Represents part of a transverse section of a fossil stem found at Tweed Mill. It is remarkable among the plants of the lower deposits for the beautiful regularity of its tissue, which resembles that of the Coniferæ, presenting the usual hexagonal apertures of the elongated cellules, and very 
distinct medullary rays, of considerable breadth. No appearances of concentric circles have been observed.

Fig. 2. Represents part of a longitudinal section of the same plant parallel to the medullary rays. Viewed in this direction, the tissue is also very regular, consisting of elongated cellules, which are quite straight, with walls marked generally with three or two series of circular bodies, always placed at some distance, usually about a semidiameter from each other, and seldom or never occupying the whole breadth of the cellules. The medullary rays are distinctly seen.

Fig. 3. Represents part of a longitudinal section perpendicular to the medullary rays. 'The tissue is composed of elongated cellules, very regular and parallel. Their walls, viewed in this direction, are continuous, and destitute of markings. The medullary rays have a breadth usually of four, or from three to five series of cellules.

The separation of the circular markings of the walls of the elongated cellules renders this plant different from the genus Pinites, in which the reticulations are contiguous, and occupy the whole breadth of the cellules. In the genus Pinus, and in other recent Coniferæ, the circular bodies or pores occur in a single series. The plants in question cannot therefore be, with strict propriety, referred to the order, although they, as well as the species of Pinites, must have been very closely allied, and the former even more so than the latter. As no fossil plant exactly resembling this has been described by authors, I propose instituting for its reception a genus bearing the name of Pitus, which is a Greek noun analogous to Pinus. 'The plant of which Figs. 1, 2, and 3. of Plate VIII. are representations, is evidently of the same species as the Lennel Braes fosssil, figured in Plates III., IV., and VII., and affords a much more characteristic specimen of it. The $\boldsymbol{P} i$ tus antiqua, then, is the first species of this new genus. A second has been found in the same place.

Fig. 4. Represents part of a transverse section of another fossil found at Tweed Mill, in which the ordinary structure of the recent Coniferæ and the fossil Pinites is distinctly seen. This species is very remarkable for the 
great breadth of the medullary rays, which are in some instances nearly equal in diameter to the intervening series of cellules.

Fig. 5. Is part of a longitudinal section parallel to the medullary rays. The elongated cellules of the woody tissue are less regular than in the last species. Their walls, however, are marked precisely in the same manner. The great breadth and regularity of the medullary rays are especially remarkable, and give the tissue, when viewed in this direction, a very peculiar aspect, which is rendered more remarkable by the frequent appearance of transverse dissepiments in the cellules of the woody fibre.

Fig. 6. Represents part of a longitudinal section parallel to the bark. The tissue is composed of elongated cellules, more or less waved, with transverse dessepiments, continuous walls, and intervening medullary rays of great breadth. I have counted as many as fifteen series of cellules in these rays, and the lowest number seems to be eight, but as sections of this kind may be more or less oblique, the number may sometimes seem more than it really is.

To this species I propose giving the name of Pitus primava.

The genus is very closely allied to Pinites, and I should not be very much disposed to censure those who might unite them, provided they kept the Piti as a section. At the same time, it presents a very different appearance from any species of that genus which I have examined.

FOSSIL PLANTS FOUND AT ALLENBANK, IN BERWICKSHIRE.

THIs locality is about seven miles from Lennel Braes, and is near the junction of the Whitadder and Blackadder. It affords a considerable va riety of fossil vegetables: Sigillariæ, Lepidodendra, and fronds of Ferns. Among these also occur large masses of fossilized remains of vegetation, of irregular forms, geserally flattened, and seldom exceeding two or three feet in length. These masses are invested with an irregular coat of carbona. ceous and clayey matter, in which are inserted small fragments of stems, shewing that it is not the true bark carbonized, but a confused assemblage 
of vegetable remains. They are evidently composed of portions of plants, of very different diameters and textures, compacted in a mass of decayed vegetable substances, broken up by crystallizations of calcareous spar; and present each, if I may so say, a whole magazine of species.

At present I intend to describe only one of these fossil bodies, of which I have been able to determine the structure with sufficient minuteness. It consists of a somewhat conical body, compressed, so as to have one diameter about a half greater than the other. When removed from the inclosing mass, it presented the appearance of natural joints, at the distance of about two inches; but I am not certain that these joints are not merely transverse cracks, for there is no enlargement or depression at the places where they occur. The extremity is rounded, and much compressed. At the lower part the larger diameter was upwards of two inches, and at the extremity one diameter is about half an inch, the other nearly a fourth. The surface is slightly striated in the longitudinal direction, and the coating consists of crystals of gypsum and calcareous spar.

Fig. 7. Plate VIII. Represents a transverse slice of a confused mass of organic remains, exhibiting the appearance offered by the fossil above adverted to, in its transverse direction. The central part of this fossil was composed of a distinct medullary cylinder, of which the tissue was for the most part destroyed. This was surrounded by a circle of exceedingly regular tissue, radiating in series of hexagonal apertures, but apparently destitute of medullary rays and vessels. The outer or marginal part is also composed of the same tissue, with an inner margin waved by the crystallization of siliceous matter ; and the intervening space presents numerous rounded portions of precisely the same appearance, in all of which the lines of cellules preserve the same centro-marginal direction. The surrounding dark portion represented in the figure, consists of numerous diversiform vegetable bodies, compacted in a confused mass, interspersed with veins and fissures filled with transparent infiltrated matter.

Fig. 8. Represents a small portion highly magnified, of the tissue surrounding the pith, as seen in the transverse section. It consists of very 
regular series of hexagonal cellules, separated at intervals by narrow spaces, resembling separations of the walls of two contiguous series of cellules.

Fig. 9. Represents a portion, magnified in the same degree, of the marginal part of the tissue, in which the same appearances are seen. The dark lines are not medullary rays. There are no concentric lines to be seen.

Fig. 10. Is part of a longitudinal section, more highly magnified, of the same portion as that represented by Fig. 8 . The cellules here also are very regular, straight, and parallel. At first sight they might be taken for spiral vessels, on account of their beautifully regular transverse linear markings; but, as it is found that the whole tissue of the plant presents the same appearance, and that these transverse lines are in fact delineated on the walls of those tubes, of which the transverse sections are presented in Figures 8. and 9 ; we must admit that the elongated cellules of the woody fibre of this plant, instead of being marked with reticulations, as in the genus Pinites, or with series of more or less separated areolæ, as in the genus Pitus, are characterized by very regular transverse lines. Some of these transverse lines are connected by lines placed at right angles, but this reticulated appearance is of rare occurrence.

Fig. 11. Represents part of a longitudinal section, magnified in the same high degree as Fig. 10, of the portion represented in its transverse section by Fig. 9. It exhibits precisely the same appearance. Figs. 10. and 11. are from slices cut parallel to the medullary rays, and therefore present the markings of those sides of the elongated cellules, which are opposite to the intercellular spaces, seen in Figs. 8. and 9.

Fig. 12. Shews the appearance of the walls of the cellules facing the pith on the one hand, and the surface of the plant on the other. These walls are marked in precisely the same manner. 'The section of a medullary ray is also seen in this figure. 'The medullary rays of this plant are so small, and placed at such distances from each other, that one might be very apt to overlook them, and transverse sections of considerable extent might be made without any of them occurring in it. However, I have fully satisfied myself that they exist. 
We are now enabled to describe the tissue of this singular plant.

The portion which I possess consists of a compressed, tapering body, several inches in length, rounded at the extremity, and resembling the termination of a stem or branch. It is slightly striated longitudinally, has no appearance of processes or the insertion of leaves, and is transversely fissured at intervals, so as to bear considerable resemblance to a calamite; but whether these fissures are indications of articulations, I am unable to say. There is a regular pith. The tissue between the pith and the surface is composed of elongated cellules or woody fibre, remarkable for their extreme regularity, being disposed precisely like those of our recent Coniferæ, but without indications of concentric circles. There are medullary rays, which are extremely sparse, and remarkable for their small size. Their transverse section presents an elliptical form. Lastly, the walls of the elongated cellules are marked all round with very regular, close, horizontal lines.

This is the first instance detected of a fossil plant affording such a texture. Whatever, therefore, may be the family to which the plant in question may be ultimately referred, it is necessary to institute a provisory genus for its reception. The transverse lines of the elongated cellules affording the most remarkable character under the microscope, the generic name Anabathra (signifying the steps of a ladder) may be selected; and the plant being distinguished for the great beauty and regularity of its tissue, the specific name pulcherrima may answer as well as any other.

We have now examined the following species of fossil plants :

Pinites Withami, Linde. and Hutr., with which

Pinites medullaris of the same authors seems to be identical;

Pitus antiqua,

Pitus primava, and

Anabathra pulcherrima. 
FOSSIL PLANTS FOUND IN THE COAL-FIELDS OF THE NORTH OF ENGLAND.

WIDEOPEN FOSSIL TREE.

A GREAT fossil tree was found in 1829 at Wideopen, near Gosforth, in a quarry upon the estate of the Reverend R. H. Brandling, on the eastern side of the great north road, and about five miles north of Newcastleupon-Tyne. It occurred in the grindstone or firestone bed, commonly known by the name of "Grindstone Post." This bed is considered one of the highest members of the coal-formation of that district, and has its name from being extensively quarried for grindstones, as well as for glass-houses and iron-furnaces, the stone being of a loosely aggregated texture, porous, and not liable to crack under the action of heat. The length of the fossil was 72 feet. It had no branches, but was rather abundantly marked with knots, indicating the places at which they had shot out. Its distance from the surface was 40 feet, of which 10 were clay, the rest sandstone.

In Plate IX. are represented transverse slices of this plant, magnified about fifty-five times.

Fig. 1. Represents a portion of a transverse slice, from one of the most regular parts. It may here be observed, that, in some portions of sections made in this direction, a tendency to the concentric arrangement seems to exist, but without any decided appearance of woody layers.

Fig. 2. A portion of the same. The appearance here presented is that usually seen, the regularity of the series of elongated cellules being altered by fissures filled with carbonaceous matter.

Fig. 3. Representation of a portion of one of the more regular parts, exhibiting the same general arrangement.

Fig. 4. From a more confused portion. The distortions produced by the partial decay and alteration of the tissue are here distinctly seen.

This plant was partially described by me in my "Observations on Fossil Vegetables;" but as I had there confined myself to transverse sections of the tissue, Messrs Lindery and Hutron instituted a further investigation 
of it, in the course of which they found the longitudinal sections to present the peculiar markings which they consider essential to the genus Pinites. They have named it Pinites Brandlingi, in honour of the proprietor of the estate on which it was found.-See Fossil Flora, Plate I. p. 1.

In Plate $\mathrm{X}$. will be seen additional delineations of the tissue of this plant.

Fig. 1. Represents part of a transverse slice, similar to those of Plate IX., but more highly magnified.

Fig. 2. Represents part of a slice taken longitudinally and parallel to the medullary rays. The reticular markings are similar to those already described as characteristic of the genus Pinites.

Fig. 3. Represents part of a slice taken in the longitudinal direction, and parallel to the bark. Several sections of medullary rays are seen; and it is remarkable that almost all of these processes in this plant consist of single series of cellules, and resemble those of the recent Coniferæ.

FRAGMENT OF FOSSIL TREE FOUND AT HILL-TOP NEAR USHAW.

THis fossil, which is in almost every respect precisely similar to the last, was found among the refuse of a quarry situated at Hill-Top near Ushaw, about four miles north-west of Durham. This quarry is in a bed of sandstone belonging to the upper part of the coal formation. Several fragments were found, probably of different species, and of which one has been figured and described in the "Fossil Flora" (Pl. XXIII, XXIV.) under the name of Peuce Withami. The fragment here represented must be essentially different, for it presents the most decided characters of a true Pinites.

Plate X. Fig. 4. Represents a portion of a transverse slice, which differs in nothing essential from the Wideopen fossil tree.

Fig. 5. Is taken from a very regular portion of a longitudinal slice parallel to the medullary rays. The acute terminations of the elongated cellules are seen; and the walls are beautifully reticulated in two, three, or sometimes four series. 
Fig. 6. Represents a portion of a similar slice, in which the reticular markings are more or less obliteratea or distorted. The longitudinal sections parallel to the bark are similar to those of the Wideopen tree; and as I am unable to perceive any specific distinction, I cannot avoid referring this fragment to the same species.

FOSSIL TREE FOUND AT HIGH HEWORTH.

A LARge fossil tree was found at High Heworth, near Gateshead, in the county of Durham. It was met with in the grindstone bed, which is the same stratum as that in which the great Wideopen tree already described and figured occurred, and was described by $\mathrm{Mr}$ WINCH in a letter to the Geological Society, dated 7th October 1817. The trunk was 28 or 30 feet long, compressed and broken, lying in the regular dip of the sandstone, declining south. Where small interstices occurred, crystals of quartz were formed. It was otherwise fine-grained in texture, and in structure somewhat lamellar, apparently from the fibre of the wood. The general colour was pale brown, but parts of it were tinged black, probably by carbonaceous matter. The bark or outer part was converted into coal.

Plate IX. Fig. 7, represents one of the most regular portions of a transverse section, and exhibits an arrangement similar to Figs. 1. and 2. of the same plate.

Fig. 8. Represents another portion of the same, exhibiting the ordinary appearance of the fossil, it being greatly distorted, and in some places intersected by earthy and carbonaceous veins. This so much resembles Fig. 2, and the texture of the fossil generally is so like that of the Wideopen tree, that the two might be supposed to belong to the same species.

Plate X. Fig. 7, represents a portion of a transverse section more highly magnified.

Fig. 8. Represents part of a section parallel to the medullary rays. The tissue of the plant generally, as has already been remarked, is much distorted. In the Wideopen and Ushaw fossils above described, the elon- 
gated cellules are usually very regular in their direction. Here, however, the case is different, their walls being more or less tortuous. This circumstance will account for the separation of the areolæ on their walls, in which respect there is often produced an appearance corresponding to that peculiar to the genus Peuce, instituted by the learned authors of the Fossil Flora, for a plant found in the same plaee as that delineated in Figs. 4, 5, and 6, of the present plate. Is it possible that these figures, and those representing the Peuce Withami, are taken from the same plant, of which the tissue has been perfectly preserved in the former, and much distorted in the latter case? I am convinced, however, that notwithstanding the different appearances exhibited by Fig. 8. of Plate X., in which the areolæ are sometimes separated, and arranged in one or two rows, the plant is very nearly allied to those found at Wideopen and Ushaw, if indeed it be not of the same species, for in some parts the regular reticulated tissue is distinctly seen to be disposed in two or three series, as characteristic of Pinites.

Fig. 9. In the longitudinal section parallel to the bark, the tissue is also distorted. The medullary rays, however, are generally shorter, and although many of them are in single rows, many also consist of two or three series of cellules; for which reason, I am inclined to consider the species as distinct. The areolæ of the reticulated walls of the elongated cellules are also somewhat larger than those of the Wideopen and Ushaw fossils. Upon the whole, this may be considered as a distinet species, to which I propose giving the name of Pinites ambiguus.

FOSSIL PLANTS FOUND IN VARIOUS PARTS OF THE COAL-FIELD.

Plate IX. Fig. 5. Represents a portion of a transverse slice of a fossil vegetable, which was found in the neighbourhood of Newbiggin, on the coast of Northumberland, where similar stems are frequently exposed to view by the action of the waters. This fossil presents a very indistinct appearance of the concentric layers. The black line in the figure, however, is apparently merely a fissure. 
Fig. 6. The portion of the same fossil here represented, is that bordering upon an irregular vein of carbonaceous or earthy matter. The dark transverse lines in this figure, like that in the last, are not truly the lines of separation of concentric layers, although some of them may occupy the space formed by the disruption of two of these layers.

This fossil seems to be of the same species as the Wideopen tree, which is also the case with another found at Westgate near Newcastle, and a specimen sent to me by Mr PHillips of York, which was found in the West Riding coal-field, together with several others from the north-eastern parts of England.

The tissue of a Pinites is readily distinguishable in a fossil plant, but although there may be many species of the genus, I am not aware of any infallible characters by which we can point them out, seeing we are confined to the organic tissue alone. Many recent pines are so similar in texture, that although a person who has dissected and compared their tissues, might be able to distinguish many of them at sight, it would yet be quite impossible to characterize them in words; and there seems no great hope of our being able to distinguish the fossil species of a genus by tissue alone, since it is so liable to be altered in its appearance, that even from the same trunk specimens might be obtained, differing so much from each other as to induce a person not aware of their common origin to consider them as distinct.

In concluding my observations on the fossils retaining organic structure, which I have found in the carboniferous series, I consider it of importance to advert to a difference in chemical composition exhibited between those of the mountain limestone series, and those of the coal formation properly so called.

As illustrative of this subject, I may present the following remarks, which were kindly transmitted to me by Mr James Johnston, Portobello, upon the Wideopen Fossil, and that of High Heworth.

" The fragments of the two fossils have the same external characters. Both are of a dark brown, from the presence of petoxide of iron, in a very 
insoluble state. About one-half of the mass of both consists of silica in a crystallized state (common quartz crystals), presenting in the cavities beautiful groups of crystals of the common form. The cavities in the High Heworth tree are more frequent and regular, forming parallel fissures, separated by thin walls of a more compact body, running in the direction of the fibres of the original wood. Under the microscope, the more compact part, portions of which occur here and there of considerable size, is seen to be composed of similar crystals, embedded in a brown amorphous substance. This brown substance prevails more in some parts of the fossil than in others; a difference due probably to the manner in which the decay of the wood took place, but shewing that any two portions of the fossil taken without selection, must vary considerably in composition. With acids, this solid portion exhibits no effervescence, nor is it dissolved by long digestion ; the lime only, and a small quantity of iron, being taken up by this treatment. Reduced to a state of coarse powder, which contained necessarily many fragments of the crystallized quartz, a portion of the Wideopen fossil gave one per cent., and of the High Heworth fossil one-half per cent. of carbonate of lime. 'The rest consisted of silica, a variable portion of alumina, and two or three per cent., probably, of peroxide of iron. As the whole fossil is a mixture only of these different substances, of which silica is the predominant ingredient, forming perhaps four-fifths of the whole mass; and as it would be nearly impossible to obtain any part of the compound or amorphous portion free from crystallized quartz, any analytical attempt to estimate the relative proportions of these ingredients would be useful only in regard to the fragment actually reduced to powder and analyzed; any other portion would be likely to give very different results. I have, therefore, considered it sufficient to determine that the lime forms a very small, and the siliceous matter a very great, proportion of the whole substance."

It has been shewn that the composition of the fossil-trees found in the mountain limestone series, differs essentially from the above, lime instead of silica being the predominating ingredient. This circumstance, besides its interest in a strictly scientific point of view, might be rendered useful to the practical investigator, it being obvious, that, in a sandstone deposit, of 
which the fossils contain much siliceous matter, the probability would be, that the deposit in question must be part of the mountain-limestone group, subjacent to the coal formation properly so called, and that, therefore, any search for extensive beds of combustible matter would prove unsuccessful.

Having now completed my investigation of the fossil vegetables retaining organic tissue, that have been found in the shale and sandstone beds of the carboniferous series, I may remark generally, that exogenous trees, or those of the Dicotyledonous Class, so far from being excluded from that series, exist in an abundance which farther examination will probably shew to be still greater than we are at present aware of. These fossil trees all present a texture very intimately allied to that of our present Coniferæ; but, as has been shewn, differing in certain respects, namely, in most instances the want of concentric circles, and in all cases in having reticulations or areolæ, in two or three series, on two opposite walls of the elongated cellules. In one or two instances, the areolæ approach very closely to those of our pines. It is, however, certain, that hitherto no structure precisely resembling that of the Coniferæ in every respect, has been found in the mountain limestone series or in the coal formation; but the alleged absence of phanerogamic trunks in these deposits has been fully, and, I trust, most satisfactorily, refuted.

REMAINS OF ORGANIC TEXTURE DISCOVERED IN COAL.

THE vegetable origin of coal has, in the more perfectly fossilized varieties, been rather inferred than demonstrated. Peat, we know, from actual observation, to consist of decayed vegetables. The process is going on under our eyes; we can watch its progress, distinguish its degrees, and observe its results. The lignites of the upper deposits are so analogous to peat, and so decidedly present traces of woody tissue, that we can have no reasonable doubts respecting their origin. Thus Bovey Coal, of which a fragment is represented in Plate XI. Fig. 1, is evidently dicotyledonous wood partially altered. In the coal beds of the lower formations, however, we cease to re- 
cognise decided appearances of vegetable matter, and in several varieties the texture is so compact or crystalline, that were analogy inapplicable, they could not be considered as organic. This is more especially the case with glance-coal, as also with the variety called pitch-coal. That coals are in general of vegetable origin, is therefore a proposition made out by analogical reasoning. I have, however, been so fortunate as to discover certain most decided traces of organic tissue, in one or two varieties of the more compact and mineralized coals. The observations which I have to offer on this subject will be best illustrated by direct reference to Plate XI.

Fig. 1. Represents, of the natural size, a fragment of Bovey Coal. This variety is evidently dicotyledonous or gymnospermous phanerogamic, for it presents all the exterual characters of stems belonging to that class. It is somewhat strange, however, that the sections, however carefully made, do not present very decided characters under the microscope.

Fig. 2. Represents a portion of a transverse slice, in which are seen indications of a tissue resembling that of the Coniferæ; but I have not succeeded in obtaining more decided appearances.

Fig. 3. Represents two portions of a piece of jet. The upper dark portion is part of a longitudinal section, of the natural size, in which the woody layers are distinctly seen. The lower is part of a transverse slice, viewed with the microscope. Indications of the woody layers are observed, but in other respects the tissue is completely obliterated.

In some species of Cannel Coal from Lancashire, I have certainly found decided traces of organization; but to what family they may have belonged I am unable to say.

Fig. 4. Represents a transverse slice of one of these specimens.

Fig. 5. Is the representation of a longitudinal slice.

The appearances, however, are so undecided, that, although I should be inclined to consider them indicative of a monocotyledonous plant, I shall not venture upon any conjecture respecting them.

Many varieties of Coal, from Berwick-on-Tweed, and the Scotch basins, on being subjected to heat, split into pretty regular layers, like those of an exogenous tree; but I have found no traces of tissue in them. I am in. 
clined to think that one of the most remarkable results of my investigations, at least it was that which struck myself most,-is the discovery of very regular texture in a variety of coal, found in the roof of a seam of that combustible in the mountain limestone group in Northumberland.

Figs. 6. and 7. Represent portions of transverse slices of this coal viewed under the microscope. The tissue is seen only in patches, but it exactly resembles that of the recent Coniferæ, and of the fossil genera Pinites and Pitus. There are regular series of roundish or subhexagonal cellules, separated by opaque spaces, which seem to be obliterated medullary rays.

Fig. 8. Represents a portion of a longitudinal section parallel to the medullary rays. The elongated cellules are very distinctly seen ; but their walls are so obscure, that only in one or two places have $I$ been able to trace reticulated appearances resembling those of the genus Pinites.

Fig. 9. Represents another portion of a similar section, the elongated cellules are sufficiently obvious; but their walls are as obscure as in the last figure.

This fossil plant, therefore, appears to me to belong to the genus Pinites, and may be named Pinites carbonaceus.

By the success which has attended my limited attempts at tracing organic texture in coal, I trust that others will be induced to pursue the inquiry. The result, I have little doubt, will bring many curious circumstances to light, and will tend to complete our knowledge of the nature of those important deposits, which have so materially contributed to the unrivalled prosperity of our island.

DESCRIPTION OF A LEPIDODENDRON OF THE COAL FORMATION, RETAINING ITS ORIGINAL TEXTURE.

IN the month of January 1832, Mr PHILlips of York having sent me a fragment of a Lepidodendron, which had been presented to him by the Reverend C. G. V. Vernon Harcourt, Rector of Rothbury, I examined 
it in the usual manner, and was delighted to find that it presented traces of its original structure. In March of the same year, I had the honour of reading to the Natural History Society of Newcastle-upon-Tyne, an account of my discovery, which was published in their Transactions.

I was the more gratified by the discovery of a texture in the interior of this fossil, as it afforded me an opportunity of corroborating the opinion of so distinguished a botanist as M. A. Brongniart, who had inferred from their external characters that the Lepidondendra were Lycopodiaceous plants. To ascertain the correctness of his views, it became necessary for me to examine the tissue of some recent species of that family, of which, however, I could at the time procure only a single species. In so far as I have discovered, the structure of that plant is analogous in most respects to that of the stem presented by Mr PHillips.

The specimens of the fossil plant in question seen by me, consist of subcylindrical or slightly compressed dichotomous stems. The surface is covered by a thick envelope of carbonaceous matter, presenting indistinct protuberances, arranged in spiral series, and beneath which are observed papillæ of an elliptical form, higher than broad. Plate XII. Fig. 1. represents a portion of one of the stems, denuded of its carbonaceous covering, and of the natural size.

Viewed in relation to its structure, the stem presents a central axis or pith, which may be seen in the transverse section, Fig. 1, $a$, Plate XIII., and in the longitudinal section Fig. 2. Plate XII.; in the latter of which it is entirely filled by calcareous spar, and a tube of carbonaceous matter. This axis consists of a central portion, which, in the transverse section, presents rather an irregular cellular tissue, around which is a layer of cellular tissue, of larger irregular polygonal cells; and, lastly, a layer with very small meshes. 'These appearances are seen in Plate XIII. Fig. 2, of which $a, b, b$, represents the pith or central part; and in Fig. 4. of the same plate, where the tissue is better preserved.

From the central column or axis, emanate on all sides, cylindrical processes, consisting of cellular tissue, with central fasciculi of vessels. They proceed obliquely upwards and outwards, as seen in Fig. $2, b, b$, of Plate 
XII, and terminate in the papillary eminences of the surface of the stem. They are seen cut obliquely in the transverse section of the stem, represented by Fig. 3. of Plate XII., where they constitute the white oblong markings dispersed in the brown parenchymatous tissue.

Fig. 4. Plate XII. Represents a longitudinal section of the stem, in which these bodies are seen, as regularly arranged as the papillæ of the surface to which they proceed.

These processes from the central axis or pith, are embedded in cellular tissue, constituting the great mass of the stem. In the transverse section of the stem, this cellular tissue presents the appearance of pretty regular meshes, assuming more or less of a polygonal form, as seen in Fig. $5, b$. Plate XII. The cellular tissue is more condensed towards the surface of the stem, as is represented at $c$ in the same figure, which also shews at $a$, the appearance of one of the processes, in which the cellular tissue and vessels have been thrust aside, and the cavity filled by calcareous spar.

The meshes of the general mass of cellular tissue are somewhat elongated in the longitudinal direction of the stem, but present the same general appearance, as may be seen in Fig. 7. Plate XII., in which there is also one of the processes partially filled by calcareous spar.

The cellular and vascular nature of these processes is pretty distinctly seen in a transverse section of one of them, Fig. 6. Plate XIII., which, though considerably altered, shews the appearance of vessels in the centre, and cellular tissue in the other parts. In the surrounding dark portion, the tissue is obliterated. The oblique section, Fig. 7. Plate XIII., shews one of these processes near its insertion into the leaf, and bears a considerable resemblance to one of Lycopodium clavatum, Fig. 9. Plate XII. Fig. 6. Plate XII. represents an oblique section, in which the meshes are more entire than usual.

From certain indications presented by some of the transverse sections of the stem, it would seem that bundles of vessels exist round the axis or pith, as seen in Fig. 4, a. $a$, and Fig. 2, $e$, of Plate XIII.

The above is the ordinary structure of the stems, as usually observed in specimens; but in a stem of somewhat greater diameter, of which a trans- 
verse section is represented by Fig. 1. Plate XIII., (much altered), the cellular or parenchymatous tissue is, at the surface of the stem, surrounded by a very thin layer of tissue, which assumes a remarkable degree of regularity, and of which some remaining portions are represented by the black curved line at $b, b, b$. It is seen magnified in Fig. 2, $d, d$, of Plate XIII., which is a portion of a transverse section, including the pith, $b, b$, and the other parts to the surface. Fig. 3. of the same plate, shews it more highly magnified. The tissue of the superficial layer has a striking resemblance to that of the woody tissue of the Coniferæ, the cellules being disposed in regular series, and of a form approaching the hexagonal, but without indications of medullary rays. In this more regular portion of the cellular tissue, circular vacuities are observed, resembling the lacunæ of the Coniferæ, or the apertures of vasa propria.

The Lepidodendra are generally supposed to be Lycopodia, or plants allied to them, and there is nothing in the structure of the present species that might tend to invalidate this opinion. A transverse section of $\boldsymbol{L y c o -}$ podium clavatum is represented by Fig. 8. Plate XII.; but as I have had no opportunity of examining the structure of any large recent species, and as I have seen no figures, it does not become me to institute any comparison. Whatever light may be thrown on the nature of the Lepidodendra by the anatomy of the present species, I must leave to persons better qualified than myself to point out; but I trust the figures which $I$ have given will be useful for comparison, should other species occur in which the structure may be found to have remained. This much is certain, that the plant above described evidently belongs to the vascular cryptogamic class, and that in its structure there is nothing to invalidate the opinion derived from the external configuration of the Lepidodendra, that they are Lycopodiaceæ.

The zeal and activity of the gentleman from whom the first specimen of this fossil was obtained, have induced me to name the species Lepidodendron Harcourtii. 
References to Plates XII. and XIII. illustrative of Lepidodendron.

\section{PLATE XII.}

Fig. 1. External appearance of the Fossil. Natural size.

2. Longitudinal section, through the centre, not including the whole breadth. Natural size.

3. Transverse section. Natural size.

4. Longitudinal section, not through the centre. Natural size.

5. Transverse section of a part towards the circumference, shewing the parenchymatous tissue, and an oblique section of one of the processes. Enlarged.

6. Transverse section, shewing an oblique section of one of the processes more perfect than usual. Enlarged.

7. Part of a longitudinal section, shewing the parenchymatous tissue, and one of the processes. Enlarged.

8. Transverse section of Lycopodium clavatum. Enlarged.

9. Portion of a longitudinal section of the same plant. Enlarged.

\section{PLATE XIII.}

FIG. 1. Transverse section of another portion of the same fossil stem. Natural size.

2. Portion of a transverse section, from the axis $a, b$, to the surface. Enlarged.

3. Portion of the same towards the surface, more highly magnified.

4. Portion of a transverse section, shewing part of the pith. Enlarged.

5. Portion of a similar section.

6. Transverse section of one of the processes. Enlarged.

7. Oblique section of one of the processes. Enlarged.

Having now completed my examination of the fossil vegetables of the Carboniferous Deposits, I proceed to the investigation of those of the Lias. It may be useful, however, here to enumerate the results of our examina- 
56 DESCRIPTION OF FOSSIL TREES OF THE CARBONIFEROUS SERIES.

tion of the carboniferous strata. Four distinct genera and nine species have been found in these deposits.

Gen. I. 1. Pinites Withami. Craigleith Quarry.

2. Pinites medullaris. Craigleith Quarry.

3. Pinites Brandlingi. Wideopen, Ushaw, Newbiggin.

4. Pinites ambiguus. High Heworth.

5. Pinites carbonaceus. Nether Witton.

Gen. II. 1. Pitus antiqua. Lennel Braes and Tweed Mill.

2. Pitus primava. Tweed Mill.

GeN. III. 1. Anabathra pulcherrima. Allen Bank.

GEN. IV. 1. Lepidodendron Harcourtii. North of England. 


\section{SECTION IV.}

DESCRIPTION OF FOSSIL TREES DISCOVERED IN THE STRATA OF THE

LIAS AND OOLITIC SERIES.

FOSSIL VEGETABLES FOUND NEAR WHITBY.

IN the Carboniferous series of England and Scotland, we have seen that several species retaining organic tissue, and referrible to four distinct genera, have been found. I am not aware that any have been discovered in the magnesian limestone, the new red sandstone, or the strata associated with them. We now enter upon the examination of the lias. Hitherto no species of Coniferous tree exactly resembling in every respect those of the present day, has occurred to me in these lower deposits. The fossil from Ushaw, which Messrs Lindlex and Hutron have described and figured as a true Coniferous tree, under the name of Peuce Withami, I am inclined to consider as a species of Pinites, because it seems to me that their examination was confined to imperfect specimens, altered and distorted, of the same plant of which I have presented figures taken from a portion retaining its original tissue in a state of perfect preservation, and which is unquestionably a true Pinites, apparently the same as $\boldsymbol{P}$. Brandlingi. My anxious endeavours to discover a true and indisputable pine, have, however, been crowned with success.

In the lower half of Plate IX. are representations of a plant of that family, of which the tissue is in the most perfect state of preservation, and of extreme beauty.

Fig. 1. Represents a transverse section of a fossil tree found in the upper lias, about a mile south of Whitby, by Mr Nicol. The fragment of which this figure represents a face, is about eight inches long, and has been split in the longitudinal direction. It has a very distinct concentric ar- 
rangement, and presents marks of two branches or twigs. The exterior is irregularly and longitudinally striated, and was covered by a layer of coaly matter. The interior is intersected by veins of clayey matter and calcareous spar. Some of the concentric layers are partially separated and dislocated by the intrusion of similar substances. The colour is dull brown, but a slice viewed by transmitted light is bright umber. This figure is of the natural size. It represents the central pith, the numerous layers of woody tissue, the interjected foreign matter irregularly tortuous, or extending between the layers, and the white divergent veins of calcareous spar.

Fig. 2. A portion of a transverse slice magnified about fifty-five times, shewing the ordinary appearance of the interior. Two of the limits of the concentric layers are seen, being filled with earthy and carbonaceous matter, which has in like manner been interposed in the direction of the medullary rays. The structure is still more distinctly seen in the next figure.

Fig. 3. A portion of a transverse slice of the same fossil, magnified about forty-five times. On comparing this and Fig. 2, with the figures representing portions of Coniferæ in Plates I. and II., it will be seen that the tissue is perfectly similar, consisting of regular series of four-sided or subhexagonal meshes, with medullary rays intervening, the apertures of the cellules nearest the outer limit of each annual layer being more or less obstructed. We have hitherto seen nothing so perfectly resembling the tissue of our recent pines.

Fig. 4. Represents a portion of the same enlarged in the same degree, exhibiting the texture in its most delicate form.

Fig. 5. This represents the central part or pith, enlarged in the same degree, together with part of the first woody layer, containing medullary rays. I can find no traces of vessels. While we wonder that so delicate and regular a texture should have survived the lapse of ages, and the ruin of worlds, we cannot but feel gratified in being enabled to trace so intimate a resemblance between plants belonging to epochs so remote from each other.

There now remains to be determined the structure of the walls of the elongated cellules, but as I have examined and caused to be figured several 
transverse sections of fossils found in the same deposits, I shall first describe them. They are represented in Plate XIV., and are uniformly enlarged in the proportion of 55 to 1, excepting Fig. 6, which is of the natural size.

Fig. 1. Portion of a transverse section of fossil wood from the upper lias, near Whitby, to the south. This wood is in concentric layers, which, viewed by transmitted light, are umber-brown. The layers are separated by calcareous spar, so as to present a broken and confused appearance. The portion represented is one of the most regular, being from near the margin, where the layers are occasionally contiguous.

Fig. 2. This figure represents part of five layers near the centre of the same fossil. The irregular interruptions of the structure are filled with calcareous spar, and are not lacunæ, of which there are no traces in the regular portions. One of the most remarkable differences in the organization of this fossil is the great difference in the breadth of the woody layers. Another is the difference in the texture, Fig. 1. presenting distinct medullary rays; while Fig. 2. wants them, being from a portion in which they are not observed. Fig. 1. also appears very different from Fig. 2. in the size and form of the cellules, but this difference arises solely from the circumstance, that the latter is from a thicker portion of the slice, similar differences in thickness producing corresponding differences in appearance, in the slices of recent plants.

Fig. 3. Portion of a slice of fossil wood from the lias near Whitby. In this wood the concentric layers are very distinct, although, in some places, they are variously distorted. This figure represents one of the most regular portions.

Fig. 4. Represents a distorted portion of the same. There are hardly any traces of medullary rays in this fossil, which is in general remarkable for the regularity and little breadth of its concentric layers.

Fig. 5. Portion of a section of fossil wood from the lias near Whitby. In this wood the concentric layers are very large and regular. It is especially remarkable for the regularity of the medullary rays, which present few intersections, but appear like continuous tubes. 
Fig. 6. Transverse slice of a small portion of the most regular part of a very large mass found in situ, in the upper lias, near Whitby. It is very much disturbed by the intrusion of calcareous spar, as is represented in the figure, which is of the natural size.

Fig. 7. Portion of the same, magnified, shewing part of two concentric layers and their junction. In the unaltered parts the structure is very regular, but exhibits few traces of medullary rays, and these not continuous. The meshes are about the size of those of our recent pines.

Fig. 8. Another portion of the same, magnified in the same degree, exhibiting the confused appearance resulting from the intervention of calcareous spar.

Fig. 9. Portion of a transverse slice of a fossil tree from the Whitby Lias, shewing part of two layers. In this tree the medullary rays are very distinct, as are the concentric layers.

Fig. 10. Portion of a transverse slice of another tree from the Whitby Lias, exhibiting the same general arrangement, but with much larger cellules.

Fig. 11. Portion of a transverse slice of a fossil tree, from the grey limestone, near Whitby. The tissue of this fossil is extremely distorted and altered by the intervention of calcareous spar, the woody fibres being thrust together in black masses. The portion represented is the most regular, many of the other parts being perfectly opaque.

Fig. 12. Portion of a transverse slice of another fossil tree from the Whitby Lias. This also is very much distorted and broken up; but as little can be learned from the exhibition of black and homogeneous masses, a portion exhibiting the regular texture of the plant has been selected.

With respect to the fossil trees of the lias generally, I have to observe, that all of them which $I$ have examined agree in the following characters. Their tissue in the transverse sections corresponds precisely with that of our Coniferæ, and more especially of the genus Pinus. They have a cellular axis or pith, distinctly marked layers of woody tissue, and medullary rays. It is probable enough that several of the trees, of portions of which I have given representations, may be specifically distinct. In particular, those re- 
presented by Figs. 6, 7, and 8. of Plate XIV. may be distinct fiom those represented by the other figures. But any one aware of the great differences in aspect presented by different portions of the same fossil stem, will perceive the difficulty of characterizing species so closely allied as those of the Whitby Lias, from their internal organization alone. I therefore renounce the attempt, and feel satisfied with describing two well characterized species, namely, that of the transverse sections of which representations have been given in the lower half of Plate IX., and that represented in its transverse section by Fig. 9, of Plate XIV.

The former of these fossils, as already mentioned, was found in the upper lias close to Whitby, and presented marks of branches. The transverse sections, Figs. 1, 2, 3, 4, and 5. of the lower part of Plate IX. shew the tissue of a pine or coniferous tree in the most perfect state of preservation. Let us now turn to Plate $\mathrm{XV}$., where there are three figures illustrative of the same plant.

Fig. 1. Represents, of a larger size, a small portion of the tissue, as viewed in a transverse slice. The cellules are obstructed towards the outer margin of the annual layer, and are in general remarkably distinct, each being bounded by well-defined walls, and completely separated from the rest.

Fig. 2. Represents part of a longitudinal slice parallel to the medullary rays, of which traces are seen in the transverse parallel lines that intersect it. The cellules are very regular, and present generally one, sometimes two, series of circular glands or areolæ, which are precisely similar to those of recent Coniferæ, figured in Plate II. The only difference presented in this kind of section is, that, in the latter, the areolæ are always in single series, whereas here they are sometimes in double series, as in the fossil genus Pinites.

Fig. 3. Represents part of a longitudinal slice perpendicular to the medullary rays, four of which are seen. They consist of single series only, as in most of the recent Coniferæ, and in their transverse sections, as seen here, exhibit from one to eight cellules.

In their Fossil Flora, Messrs Lindeey and Hutton have proposed 
the name Peuce as the generic title of all fossil wood "that appears absolutely coniferous." In describing the species which they have done me the honour of naming Peuce Withami, and which very closely resembles the plant which I have named Pinites ambiguus, they have detailed the peculiar characters of the genus, which are precisely those exhibited by the fossil stem or branch described above. I have reason to think that the Peuce Withami is in reality a Pinites, and that the figures represented by the learned authors of the Fossil Flora, were taken from a distorted portion of the fossil, of which I have presented the regular and perfectly preserved tissue in Plate X. Figs. 2, 4, 5, and which I conceive to be of the same species as Pinites Brandlingi. It seems to me to be only when the cellules of the woody tissue are perfectly straight, that these plants exhibit unaltered their reticulated or areolar markings. Whatever may be the fate of Peuce Withami, I trust the characters of the plant above described as occurring in the Whitby lias, are not liable to misrepresentation. In this hope, and considering the species less liable to dispute than almost any which I have examined, I take the liberty, usually acceded to the first describer of a species, and bestow upon it the name of Peuce Lindleii.

The plant represented by Fig. 9. of Plate XIV, is also represented in its longitudinal sections by Figs. 4, and 5, of Plate XV, which are from a fragment possessing similar characters, although not from the same spot.

Fig. 4. Represents portions of five of the woody fibres or elongated cellules in their most perfect state. The general appearance of sections made in this direction is confused, the walls appearing as if covered with minute granules or areolæ as in Fig. 5 ; but in one small portion the appearance here exhibited was presented. The areolæ are precisely those of our recent Coniferæ; circular, of two concentric lines, transparent in the centre, a little depressed when close to each other, but generally separated, sometimes to a great distance. Part of one of the medullary rays is seen in the figure. This and the next figure are magnified in a higher degree than the preceding three.

Fig. 5. Is part of a longitudinal slice cut parallel to the bark, and represents several of the elongated cellules, having their walls covered with 
minute reticulations or granules, and one of the medullary rays, which have cellules always in a single series, and varying from ten to twenty or more.

This species I would honour with the name of an esteemed friend. I therefore propose that it be denominated Peuce Huttonii.

I have already remarked, that it seems to me difficult to characterize the other species of the Whitby lias; and all the longitudinal sections that I have seen are so similar in their characters, that I can only say of them that they all belong to the genus Peuce. Further investigation may elicit specific distinctions, for it is not likely that all the fossil trees of the lias of a whole district should be of two species only.

FOSSIL TREE FOUND IN THE OOLITIC DEPOSITS OF THE HEBRIDES.

In Plate XIV. (Figs. 13. and 14.) will be seen representations of two small portions of a transverse section of a fossil plant found in the island of Eig, one of the Inner Hebrides, which was briefly described by me in my "Observations on Fossil Vegetables," and afterwards more fully described and figured by the authors of the "Fossil Flora," under the name of Pinites eggensis. I shall first advert to the figure and description in the work last mentioned, and then proceed to my own representation of the plant in question.

In Plate XXX. of the Fossil Flora is represented part of a transverse slice magnified 180 diameters, and including portions of four annual layers. "In structure," it is said to be " obviously different from any of the coal Coniferæ; its medullary rays appear to be more numerous, and frequently are not continued through from one zone of wood to another, but more generally terminate at the concentric circles; it abounds in turpentine vessels, or lacunæ of various sizes, the sides of which are distinctly defined; and here and there, rows of flattened tubes are found among the ordinary cylindrical woody tissue. These are distinctly visible in a cross section."

The fossil in question was found at the base of the magnificent mural 
escarpment named the Scuir of Eig, not however, I believe, in situ, but among fragments of rocks of the oolitic series. These beds are so similar to those of Troternish in the Island of Skye, that it is difficult, on minute comparison, to distinguish them. According to Messrs Sedgewick and Murchison, the Troternish beds are the upper strata of the great oolitic series, and resemble the Cornbrash and Forest Marble. The fossils of the lias generally are of a light brown colour, but this is remarkably dark, being of a deep black hue when viewed by reflected light, and dark-brown when seen by transmitted light.

The tissue in a transverse slice viewed with the naked eye, is disposed in concentric layers, the boundaries of which are very distinctly marked. The medullary rays are numerous, and in the tissue are scattered oval or roundish lacunæ of various sizes. In a slice about three inches in diameter, and including only part of one side of the stem or branch, I have counted thirty-three woody layers.

Plate XV. Fig. 6. Represents the entire breadth of three layers and part of a fourth, as seen in a transverse slice under the microscope, and magnified in the same degree as the three upper figures of the same plate. It is seen that the transverse sections of the elongated cellules of the Eig fossil, are much less in diameter than those of the fossils of the English lias. Two of the lacunæ are represented: they exhibit the appearance of large oblong apertures in the woody tissue, generally filled, when the slice is somewhat thick, with reticulations. The medullary rays, al. though very distinct, are frequently not continuous from the centre outwards, but are interrupted at the outer margin of the woody layers. The tissue in other respects resembles that of the recent Coniferæ, and of the fossil genera Peuce, Pinites, and Pitus.

Fig. 7. Represents a portion of a transverse slice, magnified nearly in the same degree as the large figure in Plate XXX. of the Fossil Flora, or about 150 times. Here the tissue is seen to present the same aspect; and although several series of cellules differ more or less in appearance from others, I am unable to see in them any real difference, nor have I any where found a tissue resembling that represented in the Plate just 
mentioned. It appears to me simply that differences in the thickness of slices, or of different parts of the same slice, produce differences in the aspect of the cellules, such as we observe, under similar cireumstances, in all the fossil stems hitherto examined. Excepting the lacunæ, or turpentine vessels, therefore, I have observed no vessels properly so called in this species, any more than in the others which I have examined.

Fig. 8. Represents part of a longitudinal section parallel to the medullary rays. The specimens which I possess are so small, and the markings in this direction are so obscure, that I have scarcely succeeded in detecting the real nature of the tissue. However, I have distinctly seen it in one portion to be as represented in the figure. The elongated cellules are very regular, and here and there present acute terminations. Their walls seem covered with minute granules or areolæ of different sizes, and not arranged in regular series. The medullary rays are regular and distinct. These minute irregular reticulations are similar to those presented by specimens from the English lias, and may be the ultimate vesicles of the cellular tissue, or transparent granules of resinous or other matter. In other species they are co-existent with the large areolæ characteristic of Peuce, and as the tissue in every other respect is similar to that of the lias trees, I am inclined to consider it not as a Pinites, but a Peuce.

Fig. 9. Represents part of a longitudinal section parallel to the bark. In this section, the structure is more distinctly seen in the specimen which I possess. The only thing remarkable that it exhibits is the very small size of the medullary rays, which always consist of one series of cellules, generally not more than from two to five cellules being placed above each other, and frequently a single one forming the ray. The sides of the cellules are also covered with minute areolæ of different sizes, and irregularly disposed.

With Peuce eggensis, I conclude my examination of the fossils of the lias and oolite, any remarks arising from a comparison of the species and genera described, may be with propriety transferred to the next section. Previous to entering upon this part of my task, however, it will be proper 
to offer a brief explanation of the remaining plate, which having been engraved for my previous work, as exhibiting several varieties of tissue, I have judged worthy of being transferred to the present.

\section{Explanation of the Figures of Plate XVI.}

THIs plate contains representations of portions of thin slices of fossil vegetables of various kinds, viewed by transmitted light, and, with the exception of Fig. 9, greatly enlarged.

Fig. 1. Part of a transverse slice of fossil wood found near Whitby, much broken up and distorted. Enlarged about fifty-five times.

Fig. 2. Portion of a longitudinal slice of part of one of the fossil vegetables found at Lennel Braes, figured in Plate VIII. It exhibits the transverse section of several medullary rays. Enlarged about fifty-five times.

Fig. 3. Represents a portion of a transverse slice of the Wideopen tree, figured in Plates IX. and X. The portion here represented is one of the most regular, and has been enlarged about 100 times.

Fig. 4. Portion of a transverse slice of a large fossil tree from New Holland, in the Museum of the University of Edinburgh.

Fig. 5. Portion of a transverse slice of the Newbiggin tree, represented by Figs. 5. and 6. of Plate IX., and here enlarged about 100 times.

Fig. 6. Represents a portion of a transverse slice of silicified fossil wood, the locality of which is unknown. It is enlarged about fifty-five times, and resembles the Coniferæ in structure.

Fig. 7. Portion of a transverse slice of Anabathra pulcherrima, figured in Plate VIII.

Fig. 8. Attached to this plant, as already mentioned at page 40, is an irregular darker-coloured mass, exhibiting regular structure in various places, and having interspersed in it numerous oval forms, of part of one of which this figure is a representation. These oval forms resemble the pith of some dicotyledonous plants, as well as the stipe of various ferns. I have not, however, satisfied myself as to their real nature. 
Fig. 9. Represents a portion of the Lennel Braes' plant figured in Plates III, IV, VII, and VIII. The fragment of organic structure at the upper corner is silicified and very regular. It presents the appearance of a line of junction of two concentric layers. This figure is of the natural size.

Fig. 10. The margin of the fragment indicated above, enlarged about fifty-five times. This figure displays the beautiful lace-like structure, broken up at the edge by calcareous spar, of which two divergent crystallizations are seen.

Fig. 11. Fossil silicified dicotyledonous wood, from Antigua, enlarged about fifty-five times. The structure greatly resembles that of the Mahogany, represented in Plate I. Fig. 10.

Fig. 12. Fossil silicified dicotyledonous wood, from Antigua, enlarged about fifty-five times.

Fig. 13. Fossil silicified dicotyledonous wood, from Antigua, enlarged about fifty-five times. The calcedonic mode of crystallization is observed at the lower part of the figure.

Fig. 14. Fossil silicified wood, from Antigua, probably dicotyledonous, and resembling Fig. 13. of Plate I.

On comparing Figs. 11, 12. 13, and 14 of this plate, with Figs. 10, 11, 12 and 13 of Plate I., it will be seen that the general resemblance is perfect.

Figs. 15. and 16. Represent portions of silicified monocotyledonous wood from Antigua, and may be compared with Figs. 14 and 15 of Plate I, which exhibit the same structure. They are enlarged about fifty-five times. 


\title{
SEC'TION V.
}

\author{
GENERAL REMARKS ON THE FOSSIL PLANTS REPRESENTED AND DESCRIBED \\ IN THIS WORK; WITH THEIR GENERIC AND SPECIFIC CHARACTERS AS \\ DERIVED FROM THEIR TISSUE.
}

THE first general remark which I have to offer respecting the fossil vegetables figured in the Plates, is, that their concentric layers present the same irregularity as those of our present trees, some of them being much broader than others in the same specimen. An inference to be made from this circumstance is, that the climate which existed at the epochs when these vegetables grew, resembled ours in the irregularity of its successive summers. If, at the present day, a warm and moist summer produces a broader annual layer of wood than a cold or dry one, and if fossil plants exhibit such appearances as we refer in recent plants to a diversity of summers, then it is reasonable to suppose that a similar diversity formerly prevailed. The remark, however, applies only to the plants of the lias and oolite.

The Coniferæ of the coal formation and mountain-limestone group have few and slight appearances of the lines by which the annual layers are separated ; which is also frequently the case with the trees of our present tropical regions. It is therefore possible, that, at the epochs of these formations, the changes of season, as to temperature at least, were not abrupt.

The cells of the fossil Coniferæ, are generally much larger than those of our present trees of the same family. Thus, Figs. 1, 2, 3, 4, 5, 6, 7 and 8, of Plate IX., which are enlarged in the same degree as Figs. 4, 5, 6, 7 and 8, of Plate I., have much larger meshes than the latter. Our observations on this subject, however, are not sufficiently numerous or correct, to 
authorise any inferences as to the comparative vigour of the vegetation of the different epochs; and in the colder regions of both continents, we have trees at the present day of much larger dimensions than those of any fossil trunk hitherto discovered.

The prevailing colour of the fossil vegetables, retaining their organic texture, which occur in our mountain-limestone series, coal-fields, and lias deposits, is brown, of various tints, more commonly wood-brown, frequently umber, and sometimes greyish or blackish brown. Those of the lower of these deposits are calcareous, as are generally the fossils of the lias, and the veins by which they are intersected are commonly of calcareous spar. In the coal-formation, siliceous matter is the principal ingredient. Those fossils, on the contrary, which, occurring in the same formations, are destitute of organic texture, have their interior filled with substances of the same nature as the strata in which they have been deposited.

In a former work I concluded my general remarks on the plants which I had then examined, in the following words: "Nothwithstanding the want of well defined concentric layers in those of the coal-formation and mountain-limestone group, no doubt remains with me of their being Coniferæ. Should it be shewn, by future investigations, that recent plants of other classes present a similarity of structure, the case will become different ; but until then, it will remain established that these fossil plants come nearer to the structure of the Coniferæ than that of any other tribe. As to the fossils of the lias, I presume no doubt can henceforth remain in the mind of any one who may compare them with recent Coniferæ, or be satisfied with the accuracy of my representations." After a more extended examination, I may repeat these words. The genera Peuce, Pitus, and Pinites, are evidently of the same natural family, and although we have not now trees resembling the two latter, they must necessarily be associated with the first, which all must allow to be a genus of Coniferæ.

I now proceed to the generic and specific characters of the plants examined. 


\section{GENUS I. PEUCE.}

A medullary axis of ordinary size; woody tissue consisting of elongated cellules; distinct concentric circles; medullary rays; bark. Stems roundish or compressed, tapering, branched.___Pith of irregular polygonal cellules. Woody tissue in the transverse section presenting the appearance of regular, parallel, radiating series of four-sided, subhexagonal cellules, with interspersed narrow medullary rays. In the longitudinal sections, the cellules are seen to be greatly elongated, with oblique dissepiments placed at great distances. Two of the walls, those facing the medullary rays, are marked with a single, sometimes a double series, of circular areolæ, more or less distant from each other. Those facing the pith and the surface are continuous, and destitute of markings. The medullary rays, in their transverse sections, usually present a single series of cellules.

This genus is peculiar to the lias and oolite, at least no species have been found in any anterior deposit.

\section{Peuce Lindleiana.}

Areolæ in one, sometimes in two, series; medullary rays in their transverse section of 1-8 cellules.

Plate IX., lower half. Figs. 1, 2, 3, 4, 5. Probably also of Plate XIV. Figs. 1, 2, 3, 4, 5, 10, 12. Plate XV. Figs. 1, 2, 3.

From various parts of the Whitby Lias.

\section{Peuce Huttoniana.}

Areolæ in a single series; medullary rays in their transverse section of 10-20 or more cellules.

Plate XIV. Fig. 9. Plate XV. Figs. 4, 5.

Whitby Lias. 
3. Peuce eggensis.

Cellules very small; lacunæ; areolæ not determined; medullary rays in their transverse section very short, of 1-8 superimposed cellules.

Plate XIV. Figs. 13, 14. Plate XV. Figs. 6, 7, 8, 9.

Island of Eig.

\section{GENUS II. PITUS.}

A medullary axis of very large size; woody tissue consisting of elongated cellules; concentric circles usually indistinct ; medullary rays; bark. Stems cylindrical or compressed, tapering, branched._-Pith of irregular polygonal cellules. Woody tissue in the transverse section, presenting the appearance of regular, parallel, radiating series of four-sided, subhexagonal cellules, with interspersed medullary rays. In the longitudinal sections the cellules are seen to be greatly elongated, with oblique or transverse dissepiments placed at great distances. Two of the walls, those facing the medullary rays, are regularly reticulated with two or three series of roundish areolæ, which are separated from each other. The walls facing the pith and the surface are continuous, and generally destitute of markings. The medullary rays in their transverse sections present irregular series of cellules, varying from four to fifteen.

The species of this genus have been found in the mountain limestone series of deposits, on the banks of the Tweed.

\section{Pitus antiqua.}

Medullary rays of four or five series of cellules.

Plate III. Plate IV. Figs. 1, 2, 3, 4, 5, 6. and 7 . Plate VII. Figs. 9, 10, 11, 12. Plate VIII. Figs. 1, 2, 3. Plate XVI. Figs. 9, 10.

Lennel Braes, and Tweed Mill, Berwickshire.

\section{Pitus primava.}

Medullary rays of 10-15 series of cellules.

Plate VIII. Figs. 4, 5, 6. Plate XVI. Fig. 2.

Tweed Mill, Berwickshire. 


\section{GENUS III. PINITES.}

A medullary axis of very large size ; woody tissue consisting of elongated cellules; medullary rays; bark; concentric circles usually indistinct. Stems roundish or compressed, tapering, branched.—Pith of irregular polygonal cellules. Woody tissue in the transverse section presenting the appearance of regular, parallel, radiating series of four-sided subhexagonal cellules, with interspersed medullary rays. In the longitudinal sections the cellules are seen to be greatly elongated, with oblique or transverse dissepiments placed at great distances. Two of the walls, those facing the medullary rays, are regularly reticulated, with two or three series of hexagonal areolæ. 'Those facing the pith and the surface are continuous, and generally destitute of markings. The medullary rays in their transverse section present irregular series of cellules, varying from one to five.

The species of this genus have been found in the mountain-limestone series, and in the coal-formation.

\section{Pinites Withami. Lindery and Hutton.}

(Pith undetermined). Concentric circles obsolete, walls of the elongated cellules, with 2,3 , or 4 series of contiguous areolæ, medullary rays of 2,3 , or 4 series of cellules.

Plate IV. Figs. 8, 9, 10, 11, 12. Plate V. Plate VI. Figs. 1, 2, 3, 4. Plate VII. Figs. 1, 2, 3, 4, 5, 6.

Craigleith Quarry, near Edinburgh, in sandstone of the mountain-limestone series.

\section{Pinites medullaris. Lindery and Hutton.}

(Pith large). Concentric circles distinct, walls of the elongated cellules reticulated with 2,3 , or 4 series of contiguous areolæ, medullary rays of $2-5$ series of cellules.

Plate VI. Figs. 5, 6, 7, 8. Plate VII. Figs. 7, 8.

Craigleith Quarry, in sandstone. 
3. Pinites Brandlingi. Lindley and Hutton. Fossil Flora, vol. I.

p. 1.

Walls of the elongated cellules reticulated with 2,3 , or 4 series of contiguous aroleæ. Medullary rays of one series of cellules.

Plate IX. Figs. 1, 2, 3, 4, 5, 6. Plate X. Figs. 1, 2, 3, 4, 5, 6. Plate XVI. Fig. 3.

Wideopen near Gosforth, five miles from Newcastle-upon-Tyne. Hill Top, near Ushaw. Newbiggin, Northumberland. Westgate, near Newcastle, \&c.

\section{Pinites ambiguus.}

Walls of the elongated cellules reticulated with 2 or 3 series of contiguous areolæ (in imperfect specimens, the areolæ separated, and disposed in one or two series). Medullary rays of 1-3 series of cellules.

Plate IX. Figs. 7, 8. Plate X. Figs. 7, 8, 9.

High Heworth near Gateshead, county of Durham.

This species in the distorted parts resembles Peuce, but it is only when the cellules are straight and the areolæ in one or two (never more) series, that the fossil can be referred to that genus.

\section{Pinites carbonaceus.}

Characters not distinct, obtained from pieces of coal found in the mountainlimestone series.

Plate XI. Figs. 6, 7, 8, 9.

These genera, namely Peuce, Pitus, anà Pinites, evidently pass into each other by a regular gradation, and therefore, in all probability, belong to the same natural family. Peuce is obviously a Conifera, and the others differ only in circumstances which do not seem to be very important. 'Thus Peuce has the woody tissue very distinctly divided by concentric circles, while in the other genera these circles are occasionally present, but more frequently absent. In Peuce the pith is not larger than in our recent Coniferæ, but in Pinites it is at least four times the size. The walls of the 
woody tissue of our recent pines are marked with single series of separated areolæ, seldom occupying their whole breadth; those of Peuce are also marked with single series of precisely similar areolæ, but some of them have also double series. In Pitus the areolæ are always in double or triple series, although still separated and usually roundish. In Pinites the areolæ are hexagonal, contiguous, and arranged in two or more series. Connecting species will probably be found, when more attention is paid to the subject; and, in fact, a single trunk often presents appearances characteristic of two genera, according to the state of its parts. Thus a Pinites regularly reticulated in its unaltered and straight cellules, becomes in some degree a Peuce, when the cellules are curved and distorted.

The question as to the real nature of the areolæ I leave to those whose examinations of recent plants have been more extensive than mine. In the fossil species they would seem to me to be rather pores than glands, although even in them " much might be said on both sides."

\section{GENUS IV. ANABATHRA.}

A medullary axis; woody tissue consisting of elongated cellules; medullary rays scattered at great distances. Stems roundish or compressed, tapering.-Pith of irregular polygonal cellules. Woody tissue in the transverse section presenting the appearance of regular, parallel, radiating series of four-sided or subhexagonal cellules, with radiating tubular ducts interposed at intervals. In the longitudinal sections the cellules have all their walls very regularly marked with parallel transverse straight lines or ridges. The medullary rays in their transverse section are of an elliptical form, and composed of irregular reticulations.

\section{Anabathra pulcherrima.}

Plate VIII. Figs. 7, 8, 9, 10, 11, 12. Plate XVI. Fig. 7.

Found at Allenbank, in Berwickshire, in the mountain-limestone series. 


\section{GENUS V. LEPIDODENDRON.}

Stems simple or dichotomous, subcylindrical or compressed, the surface covered with prominences of an elliptical form, arranged in spiral series. A central axis or pith of irregular polygonal cellules, which are smaller towards the margin. The great mass of the stem composed of uniform parenchymatous tissue. Cylindrical processes of cellular tissue, with a central fasciculus of vessels proceeding from the pith to the papillæ on the surface.

These plants resemble Lycopodium in structure and in external appearance.

\section{Lepidodendron Harcourtii.}

Plates XII. and XIII.

Coal-formation of the north of England.

The result of my labours, as has been seen, is the description of twelve species of fossil plants, viewed with reference to their organic texture. The benefit which may be derived from my humble efforts may not be of great importance; but I shall enjoy the pleasure of having solicited the attention of geologists to the internal structure of fossil plants generally, and of having shewn the way to the accurate investigation of them. One great object which I had in view, when I published my imperfect views of the subject, two years ago, namely, that of directing to it " the attention of some of the many eminent botanists and geologists of which our country can boast," has already been in some measure accomplished; and any assistance which I can afford, I shall always be ready to accord to those who may feel interested in the subject. 
APPENDIX, CONTAINING AN ACCOUNT OF THE MODE OF PREPARING RECENT AND FOSSIL PLANTS FOR MICROSCOPIC EXAMINATION.

Slices of recent woods of all kinds are easily made, but it requires considerable dexterity to obtain them free of distortion, and of the necessary tenuity. A little practice, however, will enable any person, who can guide his hand steadily, to succeed to his satisfaction. When the slices are obtained of the necessary thinness, they ought to be placed between two small plates of glass, which are kept together by applying gum, sealing-wax, or any adhesive substance round their edges. The best instrument is a broad knife, thin in the back, with a straight and very sharp edge.

In preparing fossil woods, the following directions may be of use. Let a thin slice be cut off in the direction required, that is, transversely or longitudinally. It is to be ground flat, and then polished. The smooth surface thus obtained is to be cemented to a piece of plate-glass, by means of Canada balsam, of which a thin layer is to be applied to the slice of fossil wood, and another to the glass. They are then placed on a plate of metal, and gradually heated over a slow fire, so as to inspissate the balsam, care being taken not to raise the heat so high as to produce air-bubbles in the fluid. The slice and the glass are then removed, and placed upon each other; the superfluous part of the balsam being squeezed out by a slight degree of pressure, accompanied with a sliding motion. When the preparation has cooled, the portion of balsam adhering to the edges of the slice is to be removed with a pen-knife, and the slice is ground down to the requisite degree of thinness, and polished.

It is proper to add, that considerable labour and time must be employed in the grinding and polishing; and those who may not be disposed to apply much of either to a merely mechanical operation, may be supplied with perfect specimens of all the plants figured in the present work, by $\mathrm{Mr}$ Sanderson, Lapidary, St Andrew's Square, Edinburgh, who has brought the art to great perfection. 


\section{INDEX TO THE PLATES.}

Plate I. Transverse Sections of Recent Vegetables.

FIG. 1. Monocotyledonous stem. Rhapis flabelliformis. Magnified 55 diameters.

2. Gymnospermous.Phanerogamic stem. Pinus balsamea. 55.

3. Dicotyledonous Phanerogamic stem. Fraxinus excelsior. 55.

4. American Fir. 55.

5. Scotch Fir, Pinus sylvestris. 55.

6. Norway Fir, Pinus Abies. 55.

7. Common Yew, Taxus baccata. 55.

8. American Cedar. 55.

9. Cycas revoluta. 55 .

10. Mahogany, Swietenia Mahogani. 55.

11. Common Oak, Quercus Robur. 55.

12. Grey Poplar, Populus canescens. 55.

13. Sanders Wood. 55.

14. Sugar Cane, Saccharum officinarum. 55.

15. Calamus. 55.

\section{Plate II. Sections of Recent Pines.}

FIG. 1. Pinus sylvestris. Transverse section. 100.

2. Longitudinal section parallel to the medullary rays. 100 .

3. - Longitudinal section parallel to the bark. 100.

4. Spruce Fir. Transverse section. 100.

5. - Longitudinal, parallel to the medullary rays. 100 .

6. — Longitudinal, parallel to the bark. 100 .

7. Weymouth Pine. Transverse section. 100.

8. - Longitudinal, parallel to the medullary rays. 100.

9 Longitudinal, parallel to the bark. 100. 


\section{Plate III. Lennel Braes' Tree, Pitus antiqua.}

Transverse section diminished one half.

$f, f, f$. Layer of carbonaceous matter.

b. Centre.

$a, a, a$. Portions retaining organic tissue.

$c, c, c$. Portions of the same nature as $a, a, a$.

$d, d, d$. Disorganized mass.

$e, e$. Indurated argillaceous matter.

Plate IV. Fossil Vegetables of Lennel Braes and Craigleith.

\section{Lennel Braes Tree, Pitus antiqua.}

FIG. 1. Transverse section of a fragment: $a, a$, organic portions. Natural size.

2. One of the organic portions. Natural size.

3. Part of one of the organic portions. Transverse section. 35.

4. Portion of the same. 55.

5. Portion of inorganic part. 35.

6. Part of transverse section. 100 .

7. Part of transverse section. 100.

Craigleith Tree of 1826, Pitus Withami.

8. Transverse section. 45 .

9. Transverse section. 45 .

10. Transverse section. 55 .

11. and 12. Portions of the same. 45. 
PLATE V. Craigleith Tree of 1830.

Plate VI. Craigleith Fossil Tree of 1830, Pinites Withami; and Branch of 1831, Pitus medullaris.

Frg. 1. Transverse section of Tree of 1830.100.

2. Transverse section of the same, 100 .

3. Transverse section. The tissue more perfect 100 .

4. Transverse section. The tissue diversiform. 100 .

5. Transverse section of a branch found in 1831, shewing the pith and woody layers. Natural size.

6. Transverse section of the pith. 55 .

7. Portion of a transverse slice, shewing the pith and woody tissue. 100.

8. Transverse section, shewing part of three woody layers. 100 .

\section{Plate ViI. Fossil Trees of Craigleith and Lennel Braes.}

\section{Craigleith Fossils, Pinites Withami and P. medullaris.}

FIG. 1. Longitudinal section, parallel to the medullary rays, of the tree of 1826. 100.

2. Longitudinal section, parallel to the bark. 100 .

3. Longitudinal section, parallel to the medullary rays, of the tree of 1830 . 100.

4. Longitudinal section, parallel to the bark, of the tree of 1830,100 .

5. Longitudinal section, parallel to the medullary rays of the fragment found in 1831.100.

6. Longitudinal section, parallel to the bark, of the fragment found in 1831. 100.

7. Longitudinal section, parallel to the medullary rays, of the branch of 1831 . 100.

8. Longitudinal section parallel to the bark. 100 . 


\section{Lennel Braes Tree, Pitus antiqua.}

9. Longitudinal section parallel to the bark. 100.

10. Longitudinal section, parallel to the bark. 100 .

11. Transverse section shewing the pith, and part of the woody tissue. Natural size.

12. Transverse section. 150 .

Plate ViII. Fossil Vegetables of Allenbank and Tweed-Mill.

Tweed-Mill Fossil, Pitus antiqua.

FIG. 1. Transverse section. 100 .

2. Longitudinal section, parallel to the medullary rays. 100 .

3. Longitudinal section, parallel to the bark. 100.

Tweed-Mill Fossil, Pitus primæva.

4. Transverse section. 100.

J. Longitudinal section, parallel to the medullary rays. 100 .

6. Longitudinal section, parallel to the bark. 100.

Allenbank Fossil, Anabathra pulcherrima.

\%. Transverse section. Natural size.

8. Transverse section of the tissue surrounding the pith. 100.

9. Transverse section of the marginal portion. 100 .

10. Longitudinal section, parallel to the medullary rays. 100 .

11. Longitudinal section of the same kind. 100.

12. Longitudinal section, parallel to the bark. 100 .

plate IX. Fossil Vegetables of the Coal Formation and Lias. Fossils of the Coal Formation.

FIG. 1. Transverse section of Wideopen Tree, Pinites Brandlingi. 55.

2. Transverse section of the same. 55 .

3, 4. Sections of the same. 55 . 
FIG. 5, 6. Transverse sections of Newbiggin Tree, Pinites Brandlingi. 55.

7, 8. Transverse section of High Heworth Tree, Pinites ambiguus. 55.

\section{Fossil Vegetables of the Lias.}

FIg. 1. Transverse section of a fossil tree found near Whitby, Peuce Lindleiana. Natural size.

2. Transverse section of the same. 55 .

3. Transverse section. 45,

4. Transverse section. 45 .

5. Transverse section, shewing part of the pith. 45 .

Plate X. Fossil Trees of Wideopen, Ushaw, and High Heworth.

FIG. 1. Transverse section of Pinites Brandlingi, from Wideopen. 100.

2. Longitudinal section, parallel to the medullary rays. 100.

3. Longitudinal section, parallel to the bark. 100.

4. Transverse section of Pinites Brandlingi, from Ushaw. 100.

5. Longitudinal section, parallel to the medullary rays. 100 .

6. A similar section. The tissue confused. 100.

7. Transverse section of Pinites ambiguus, from High Heworth. 100.

8. Longitudinal section parallel to the medullary rays. 100.

9. Longitudinal section, perpendicular to the medullary rays. 100 .

PLATE. XI. Structure of Coal.

Fig. 1. Bovey Coal. Natural size.

2. Bovey Coal. Transverse. 100.

3. Jet. Natural size.

4. Cannel Coal, from Lancashire. Transverse. 100.

5. Longitudinal section of the same. 100 .

6. Transverse section of Coal, Pinites carbonaceus. 100.

7. Transverse section of the same. 100 .

8. Longitudinal section of the same, parallel to the medullary rays. 100 .

9. Longitudinal section. 100. 


\section{PLATE XII. Lepidodendron Harcourtir.}

FIG. 1. External appearance of the Fossil. Natural size.

2. Longitudinal section, through the centre, not including the whole breadth. Natural size.

3. Transverse section. Natural size.

4. Longitudinal section, not through the centre. Natural size.

5. Transverse section of a part towards the circumference, shewing the parenchymatous tissue, and an oblique section of one of the processes. 55 .

6. Transverse section, shewing an oblique section of one of the processes more perfect than usual. 55 .

7. Part of a longitudinal section, shewing the parenchymatous tissue, and one of the processes. 55 .

8. Transverse section of Lycopodium clavatum. $\mathbf{5 5}$.

9. Portion of a longitudinal section of the same plant. 35 .

\section{PLATE XIII. Lepidodendron Harcourtir.}

FIG. 1. Transverse section of another portion of the same fossil stem. Natural size.

2. Portion of a transverse section, from the axis $a, b$, to the surface. 12 .

3. Portion of the same towards the surface. 55 .

4. Portion of a transverse section, shewing part of the pith. 55 .

5. Portion of a similar section.

6. Transverse section of one of the processes. 55 .

7. Oblique section of one of the processes. 55.

\section{PLATE XIV. Fossil Vegetables of the Lias.}

Fig. 1. Transverse section of fossil wood, from the upper lias, near Whitby. 55.

2. Transverse section of the same. 55 .

3. Transverse section of fossil wood, from the lias, near Whitby. 55 .

4. Distorted portion of the same. Transverse. $\mathbf{5 5}$. 
FIG. 5. Transverse section of another portion of fossil wood, from the Whitby lias. 55 .

6. Transverse section of a small portion from a large mass of fossil wood, found in the upper lias, near Whitby. Natural size.

7, 8. Transverse sections of the same. 55 .

9. Transverse section of a fossil tree from the Whitby lias. 55 .

10. Transverse section of another fossil tree, from the Whitby lias. 55 .

11. Transverse section of a fossil tree, from the grey-limestone, near Whitby. 55 .

12. Transverse section of another fossil tree, from Whitby lias. 55.

13, 14. Transverse sections of a fossil tree from the Island of Eig. 55.

PLATE XV. Fossil Vegetables of the Lias.

FIG. 1. Transverse section of the Whitby tree, figured in Plate IX., Peuce Lindleiana. 100.

2. Longitudinal section, parallel to the medullary rays. 100 .

3. Longitudinal section, parallel to the bark, 100 .

4. Longitudinal section of Peuce Huttoniana. 150.

5. Longitudinal section of the same, parallel to the bark. 150.

6. Transverse section of Peuce eggensis. 100.

7. Transverse section. 150.

8. Longitudinal section, parallel to the medullary rays. $\mathbf{1 5 0}$.

9. Longitudinal section, parallel to the bark. 150 .

\section{PLATE XVI.}

FIG. 1. Transverse section of fossil wood, found near Whitby. 55.

2. Longitudinal section, parallel to the bark, of the Lennel Braes' tree. 55.

3. Transverse section of Wideopen tree. 100.

4. Transverse section of a fossil tree from New Holland. 55 .

5. Transverse slice of the Newbiggin tree. 100.

6. Transverse slice of silicified fossil wood. 55 . 
7. Transverse section of Anabathra pulcherrima. 100.

8. Transverse section of a body connected with the last. 100.

9. Transverse section of Lennel Braes' tree. Natural size.

10. Transverse section of the same. 55 .

11. Transverse section of silicified dicotyledonous wood from Antigua. 55.

12, 13, 14. Transverse sections of silicified dicotyledonous wood, from Antigua. 55.

15, 16. Transverse sections of silicified monocotyledonous wood, from Antigua. 55.

THE END. 
PLATEI，
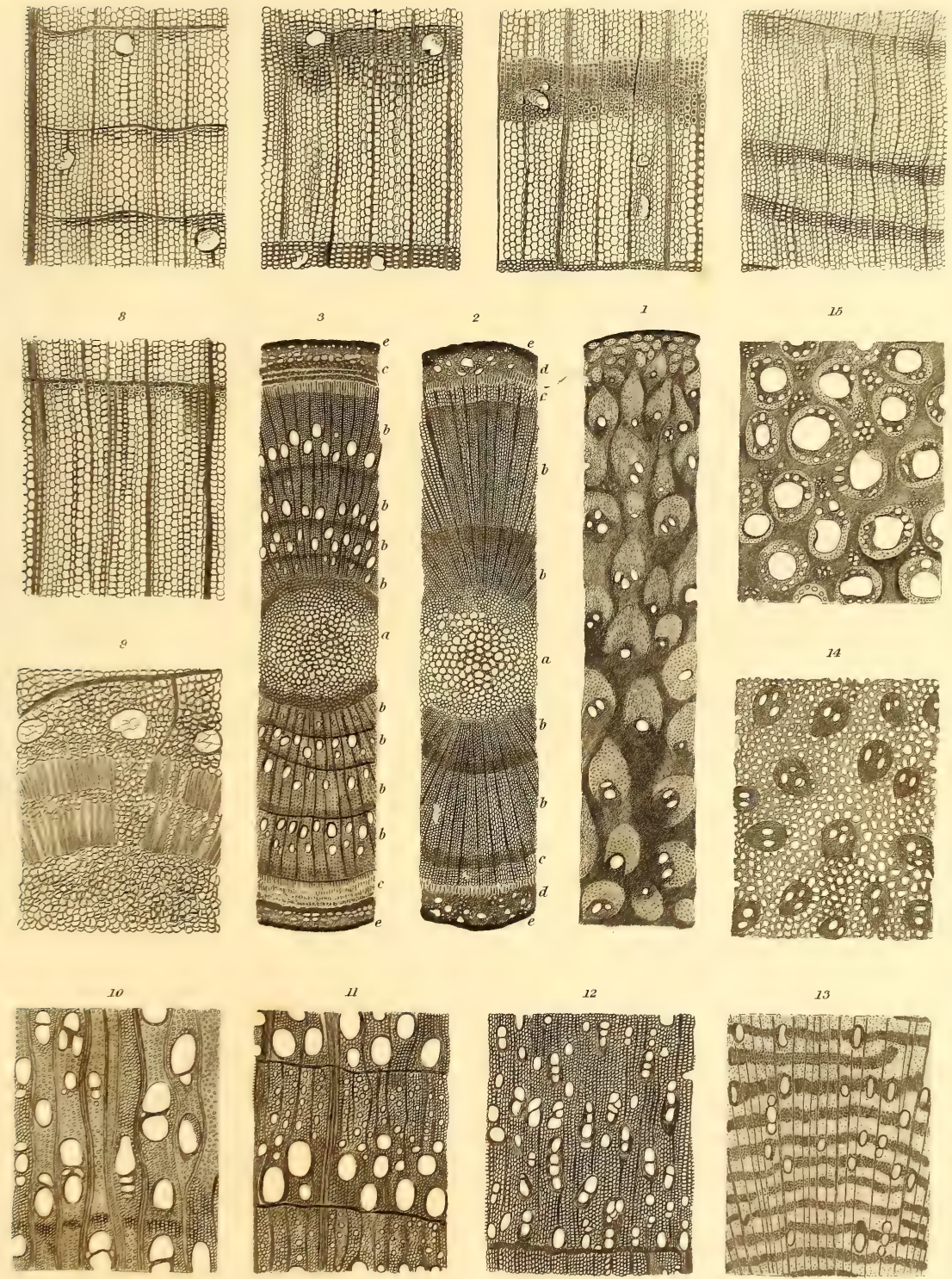


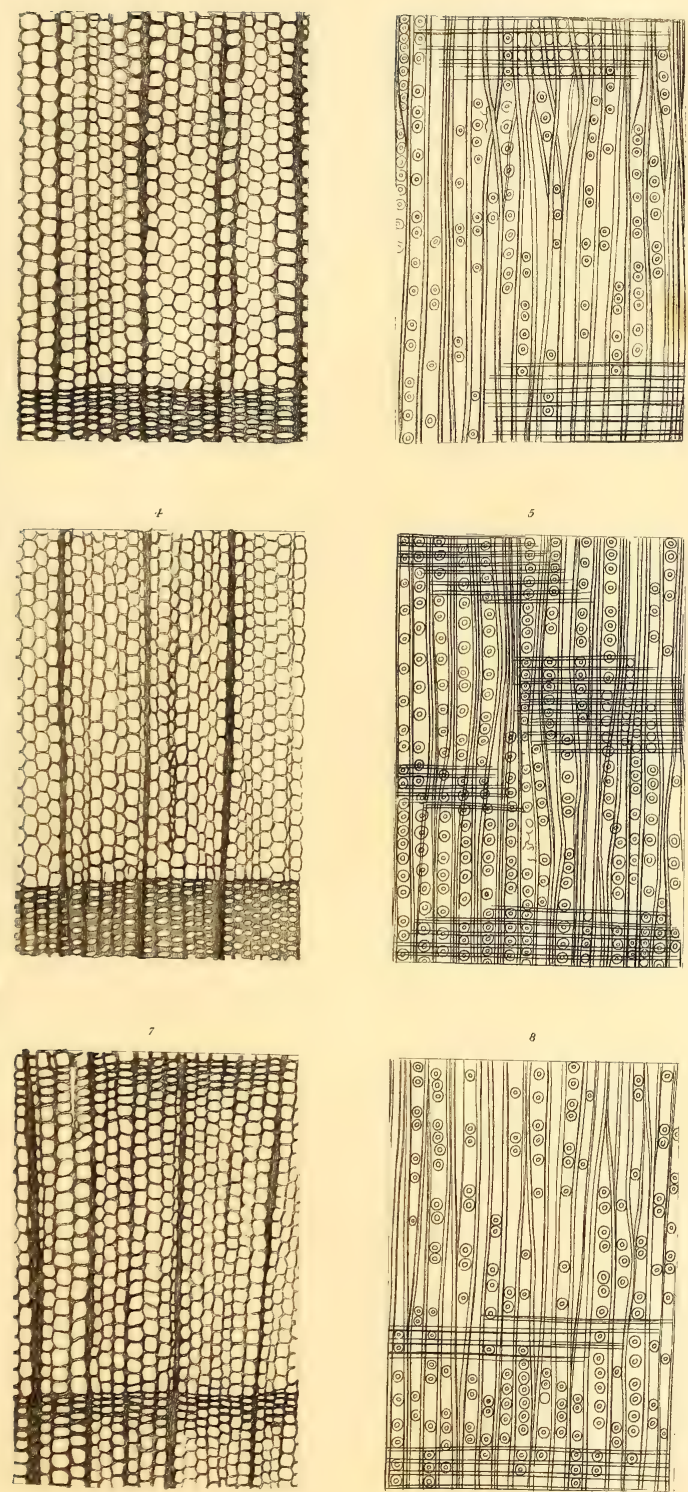
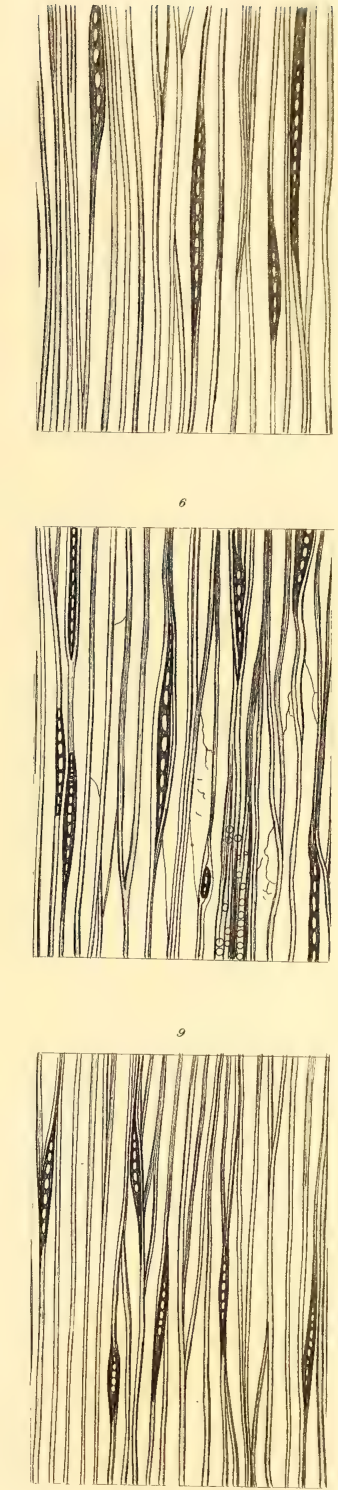



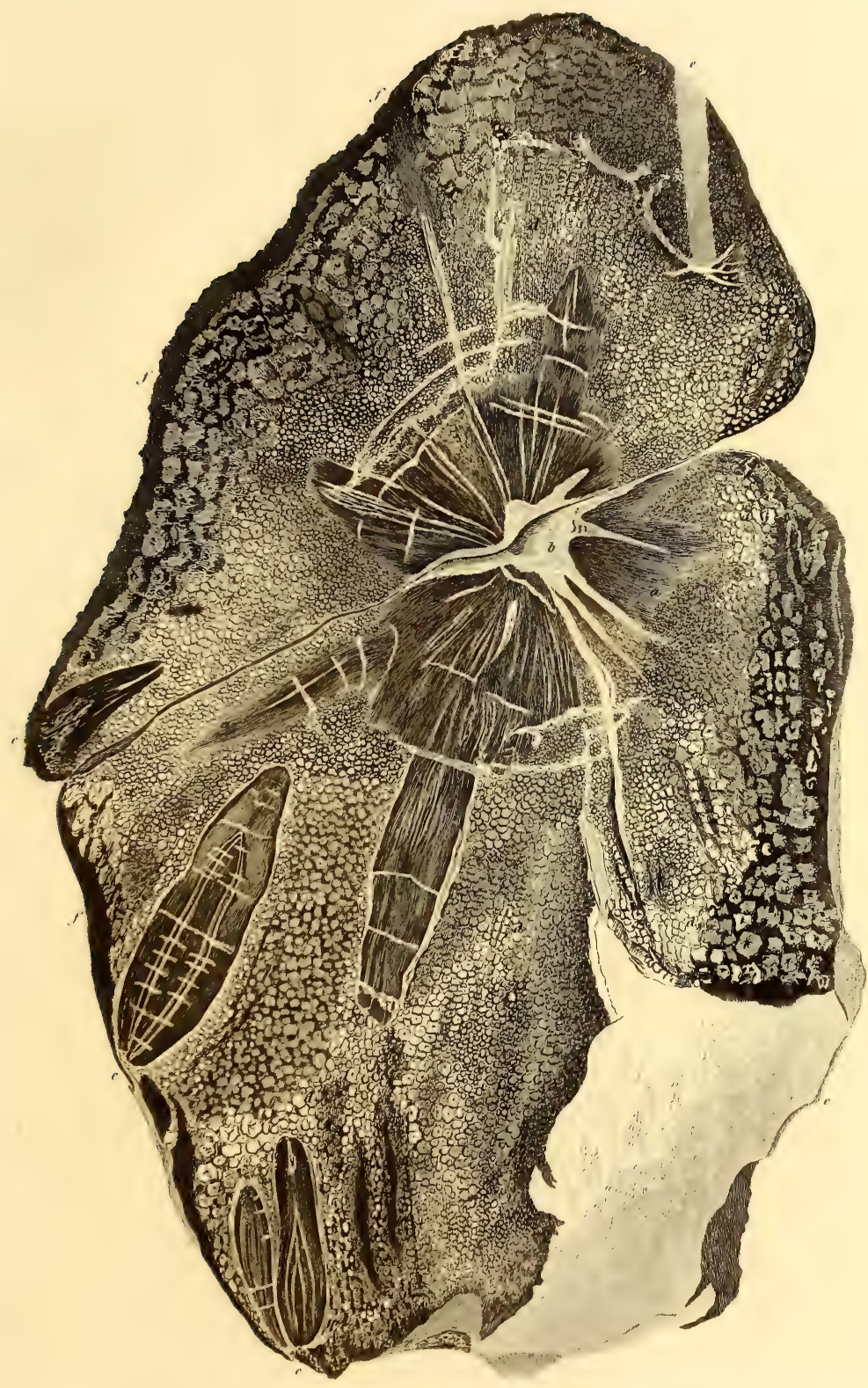



PIWATTE IV.
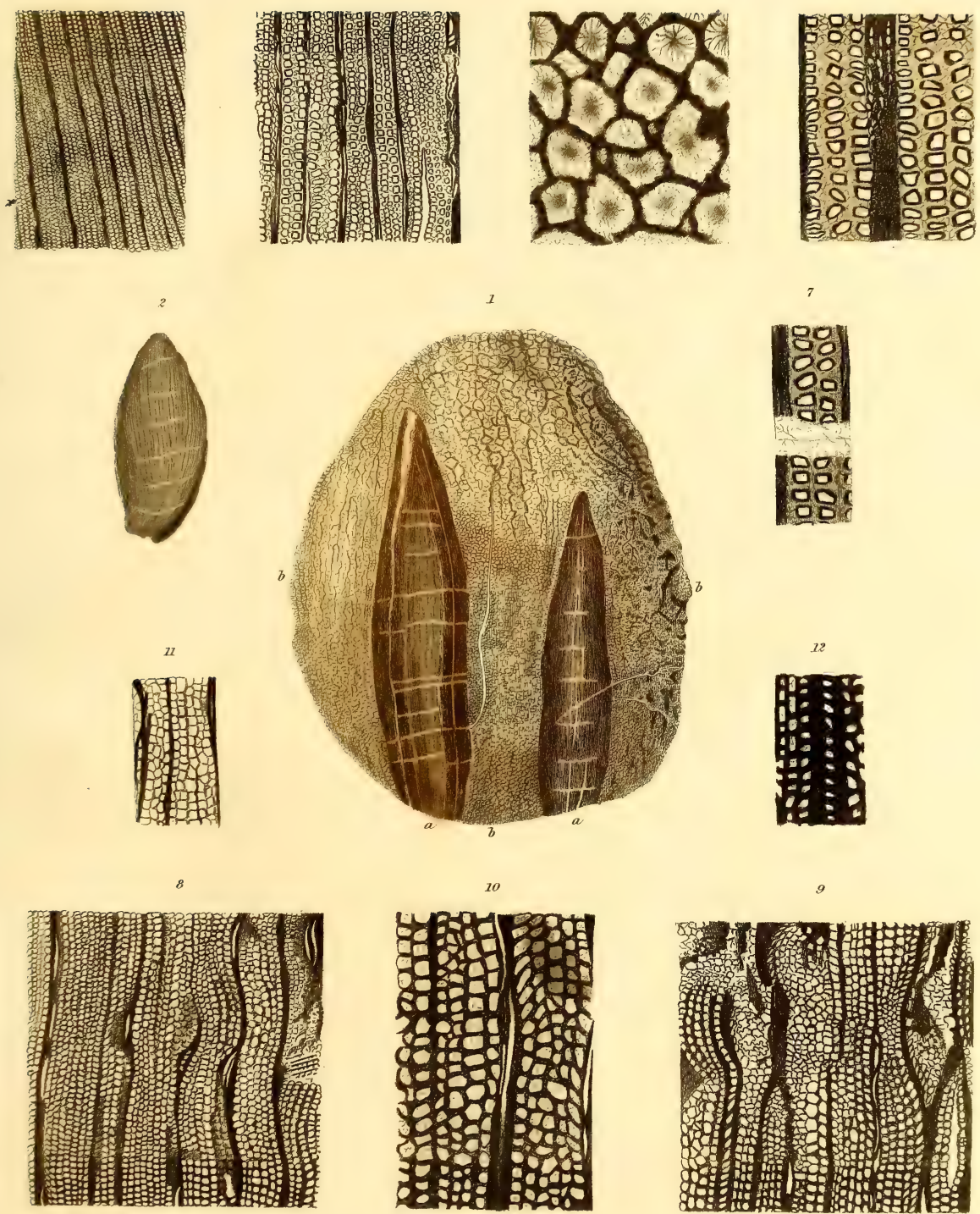



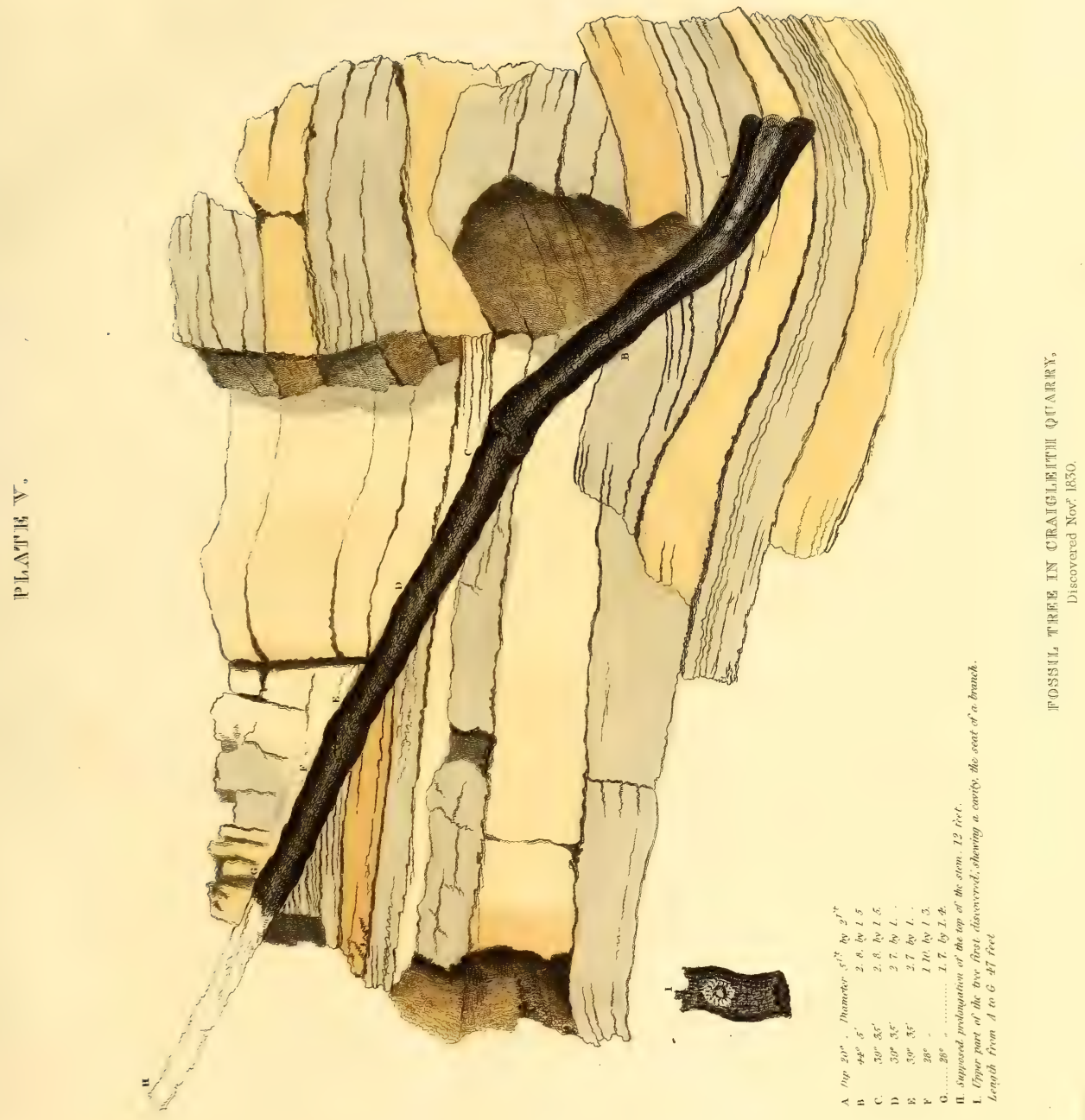




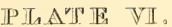
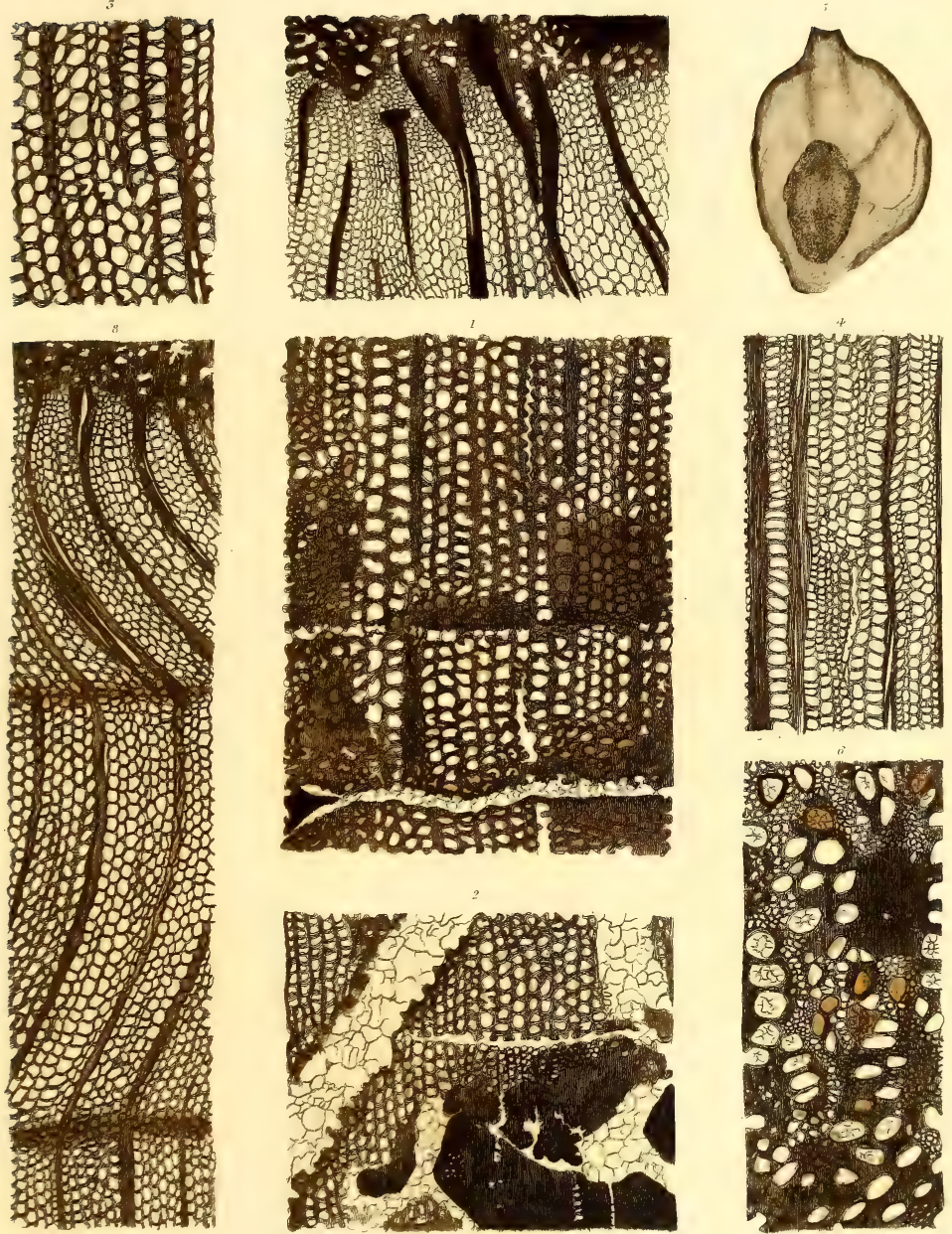


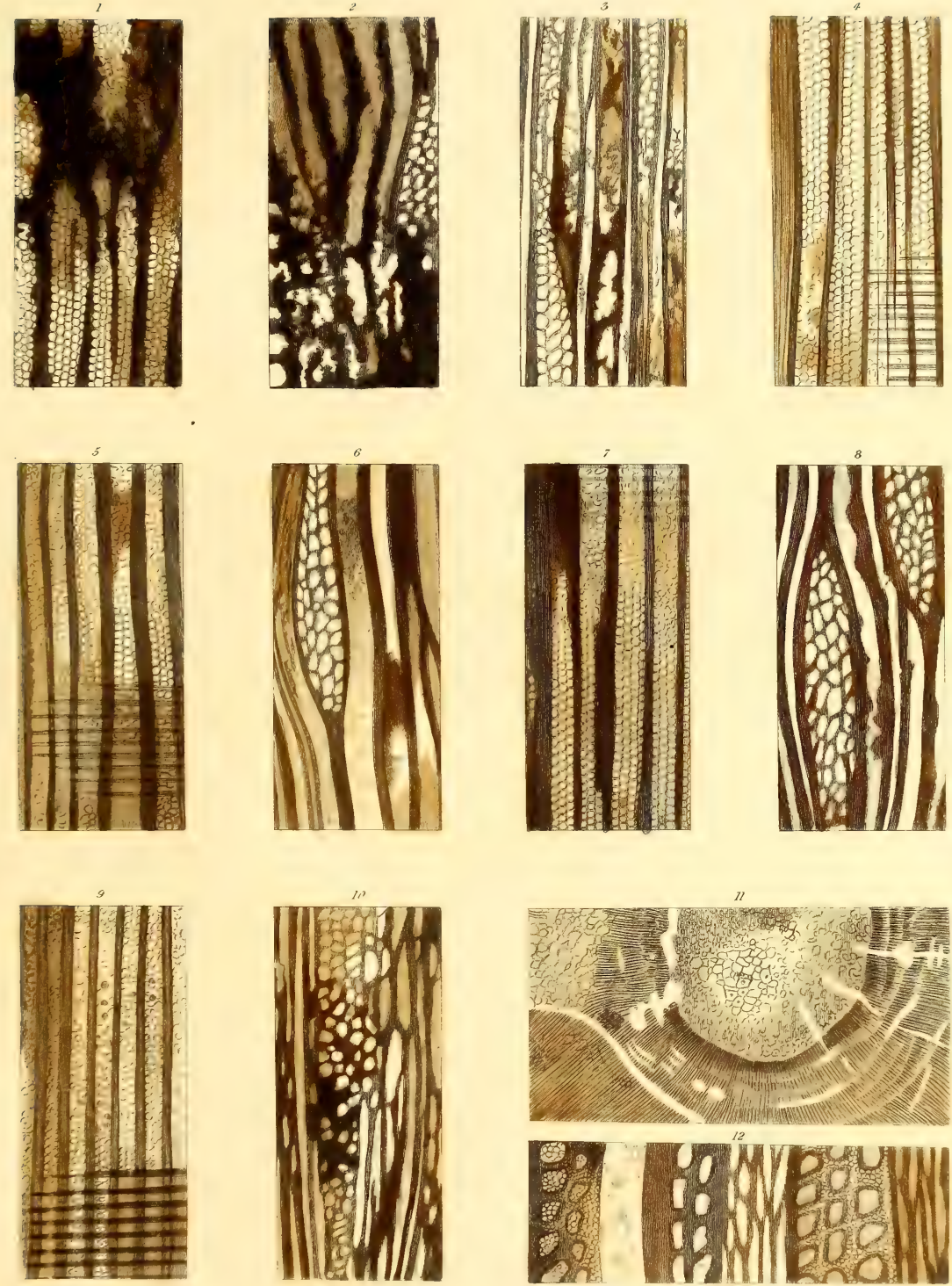


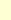



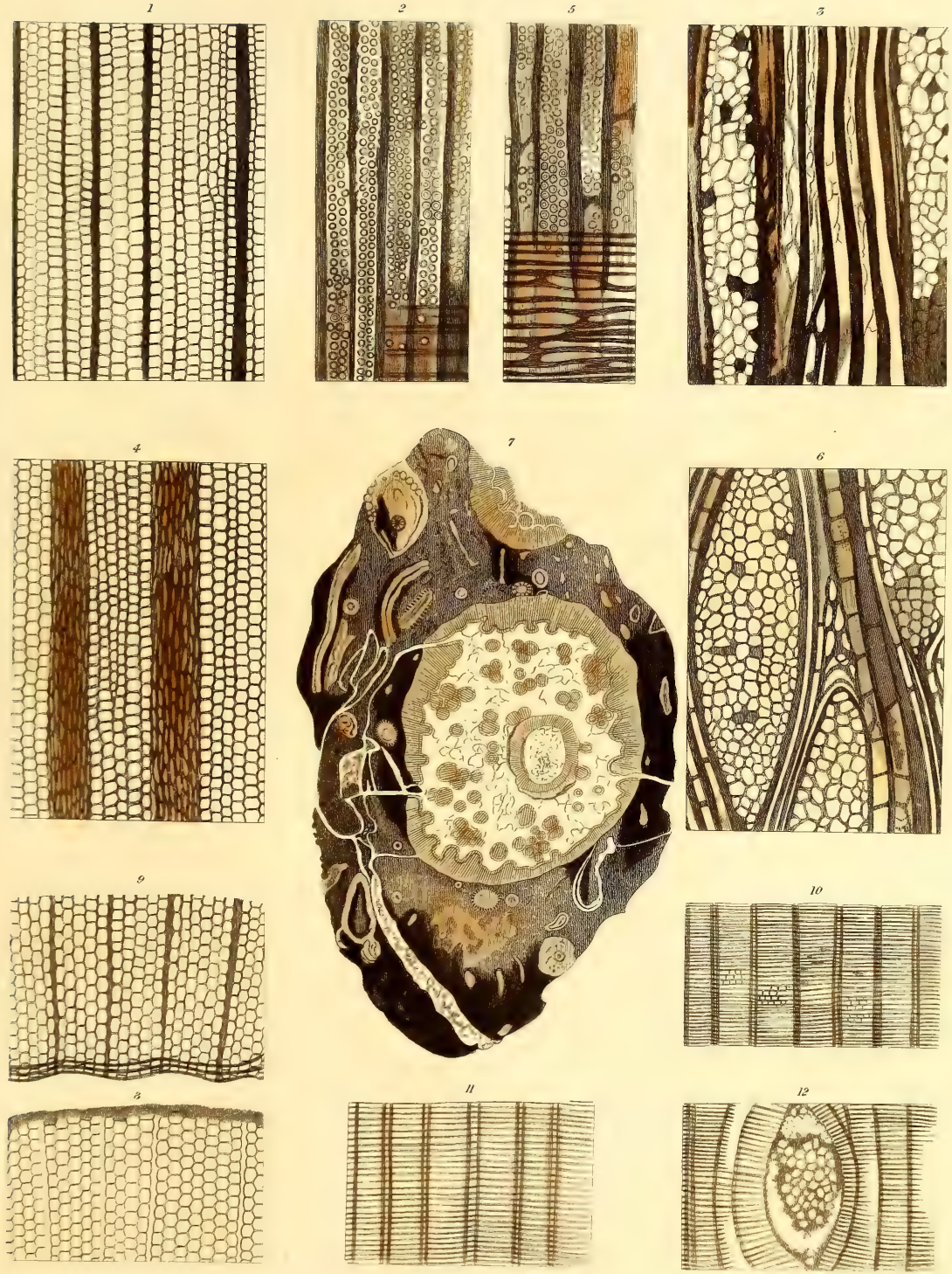


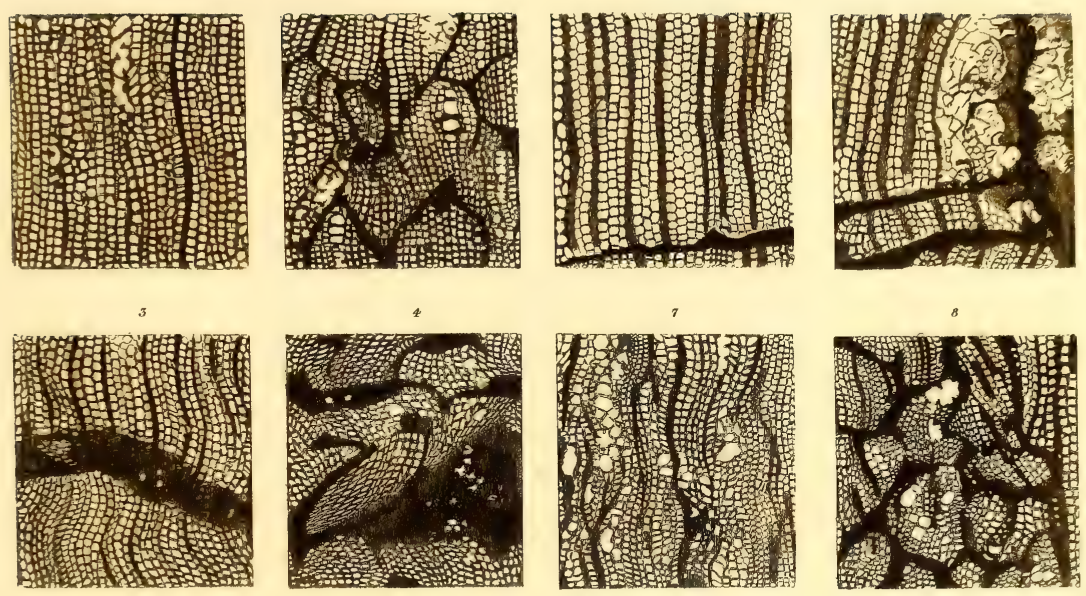

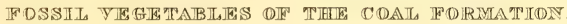
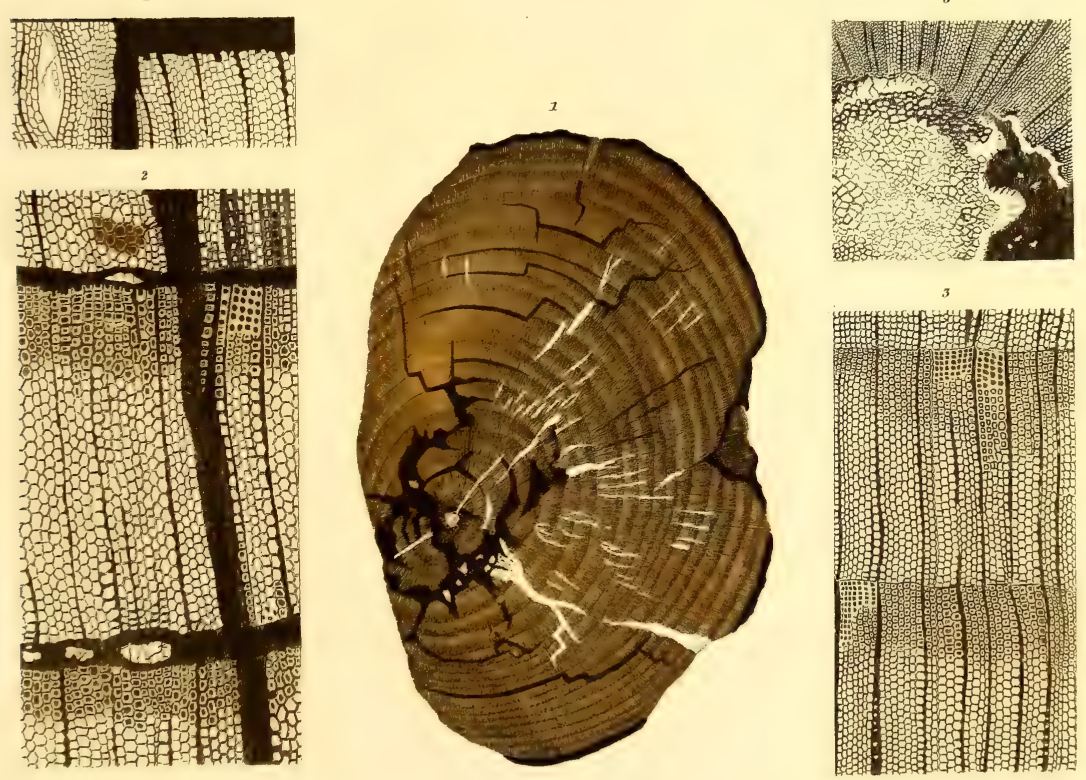

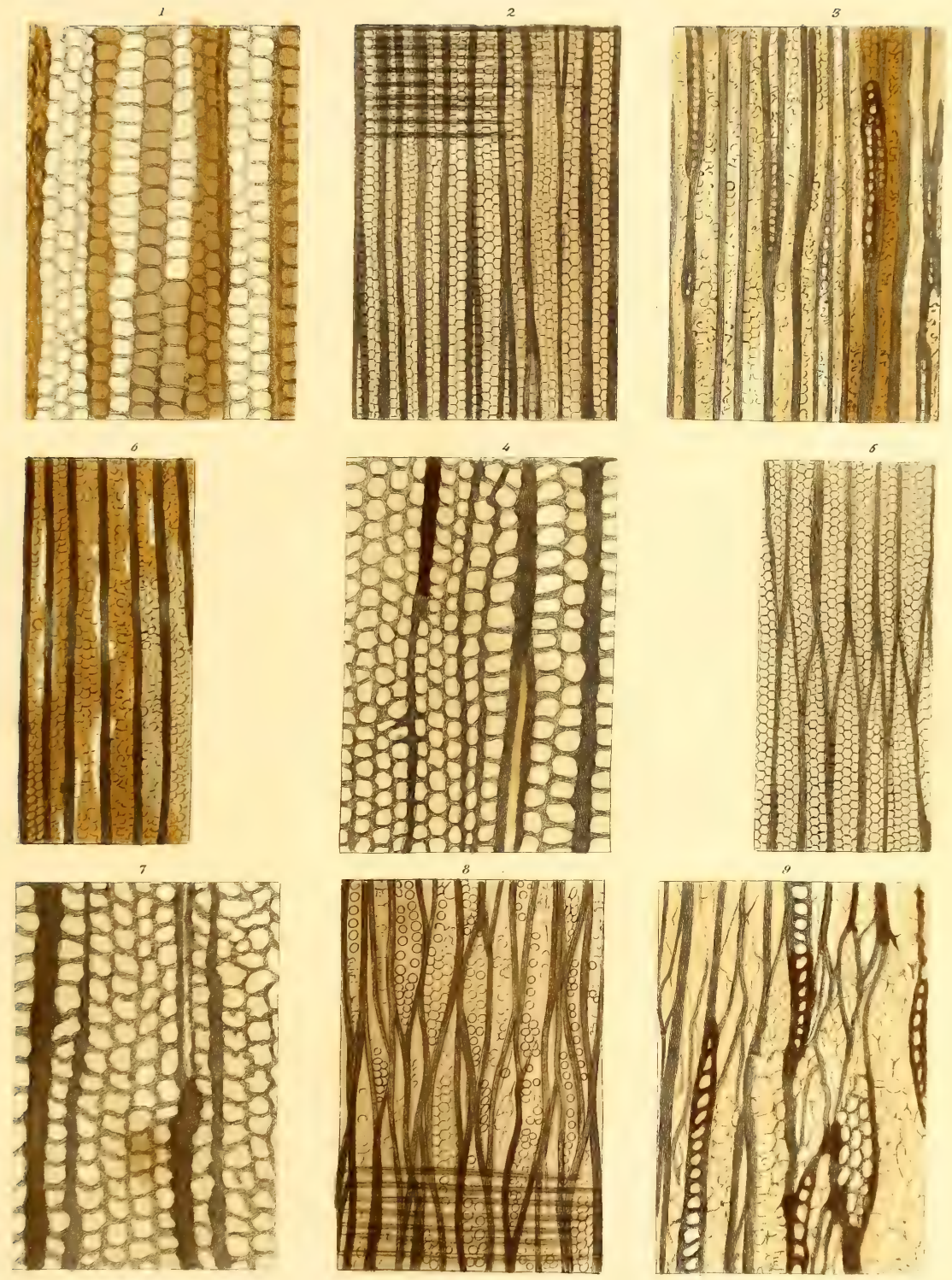


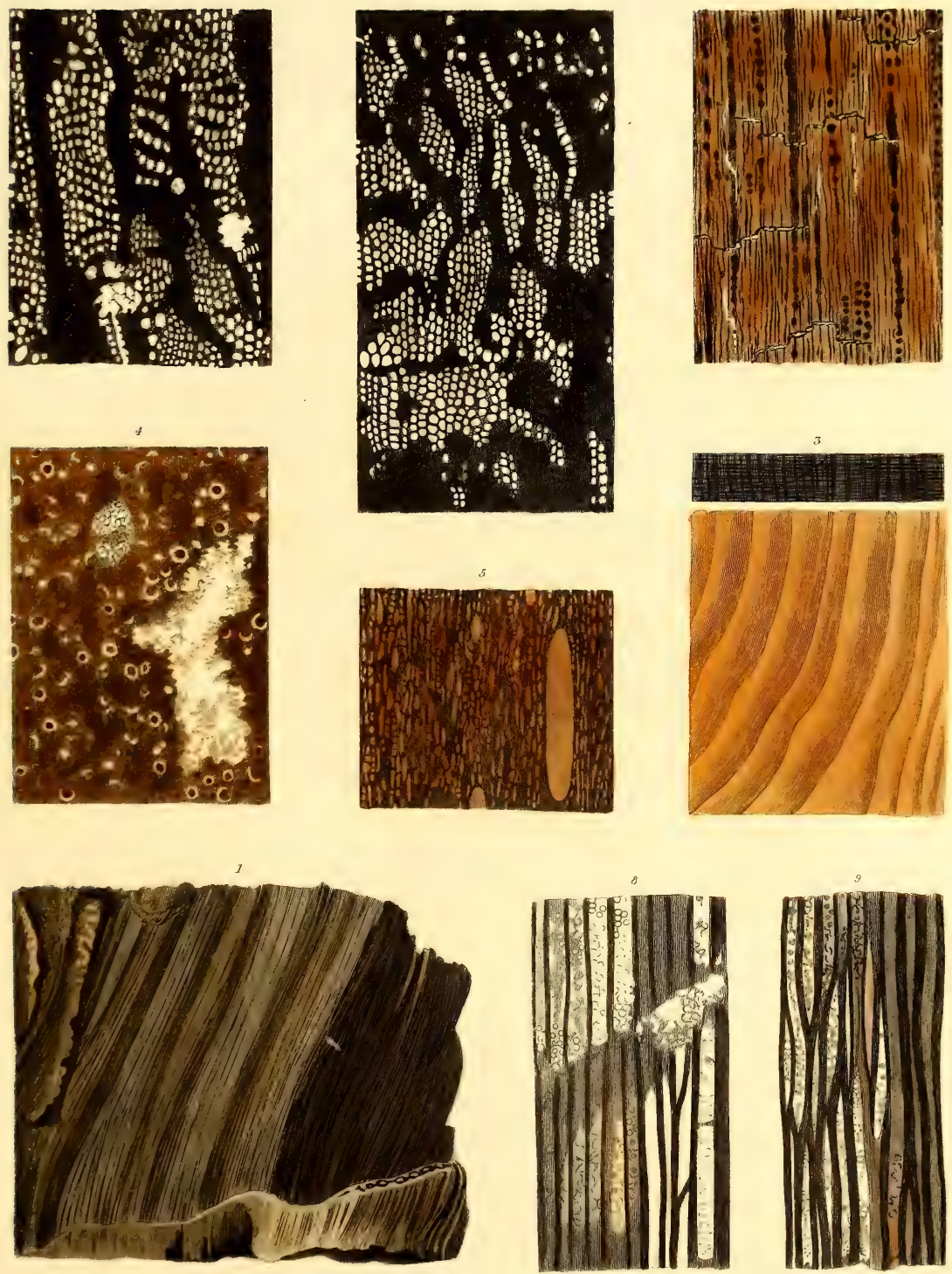


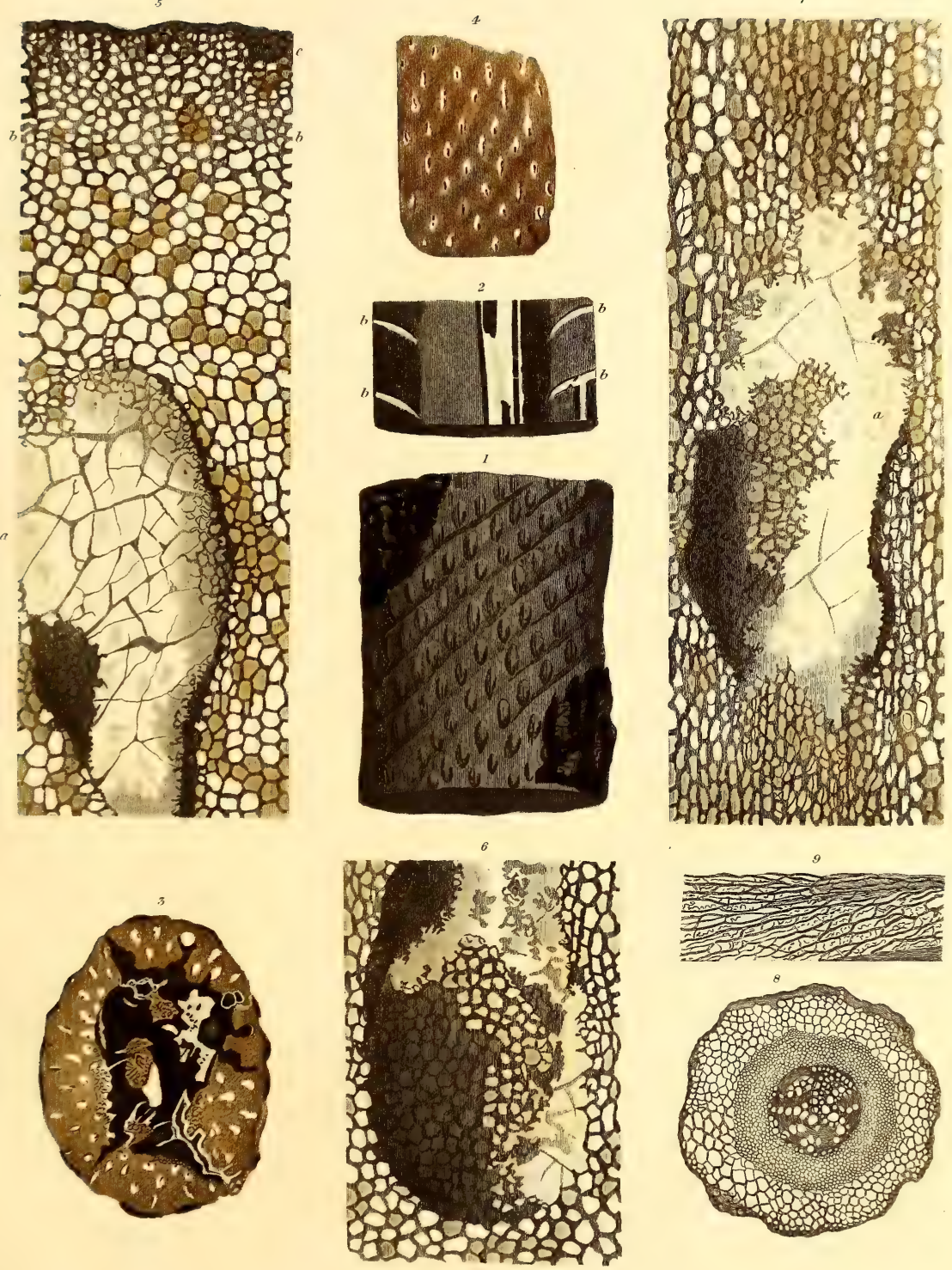


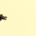


PLATE XIIII.
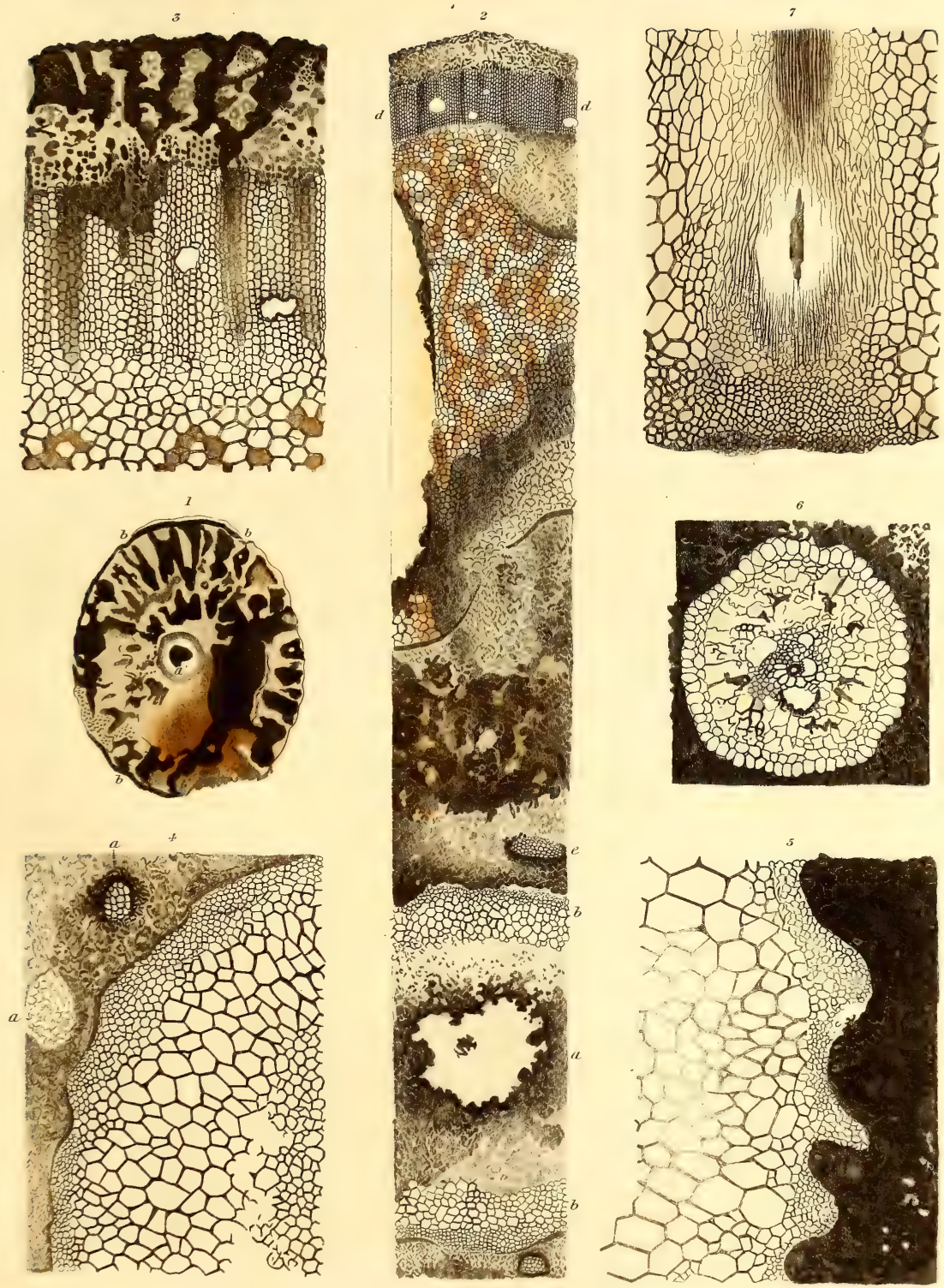

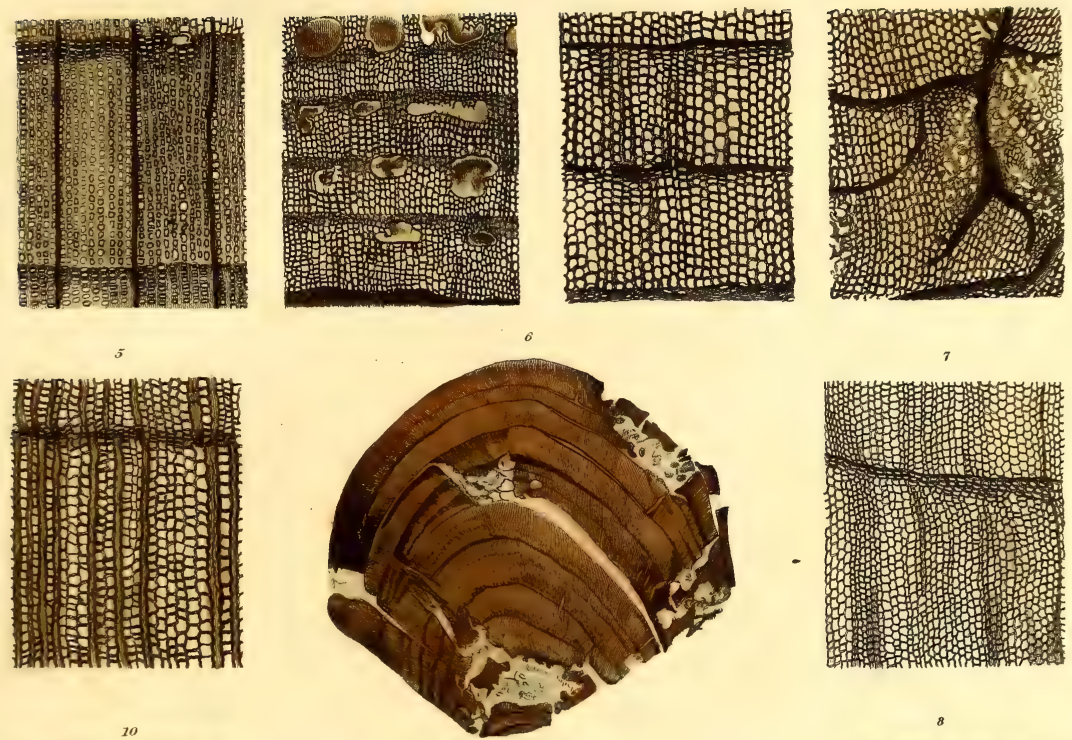

10

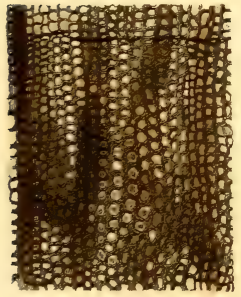

17

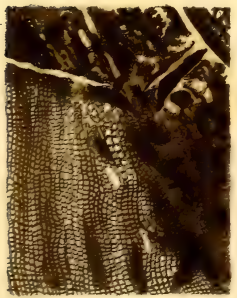

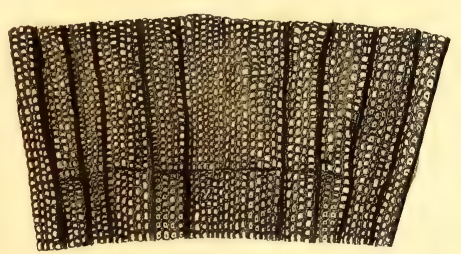

13

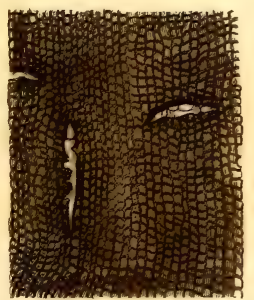

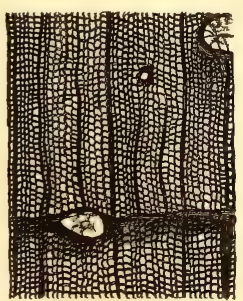
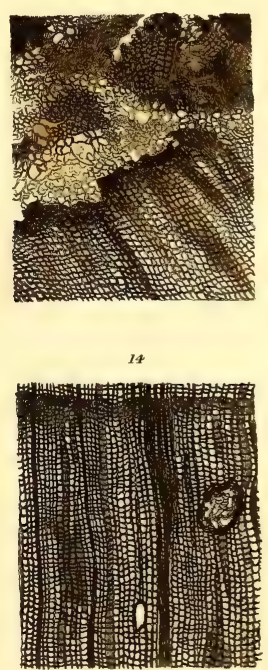

14 


$$
\text { - }
$$



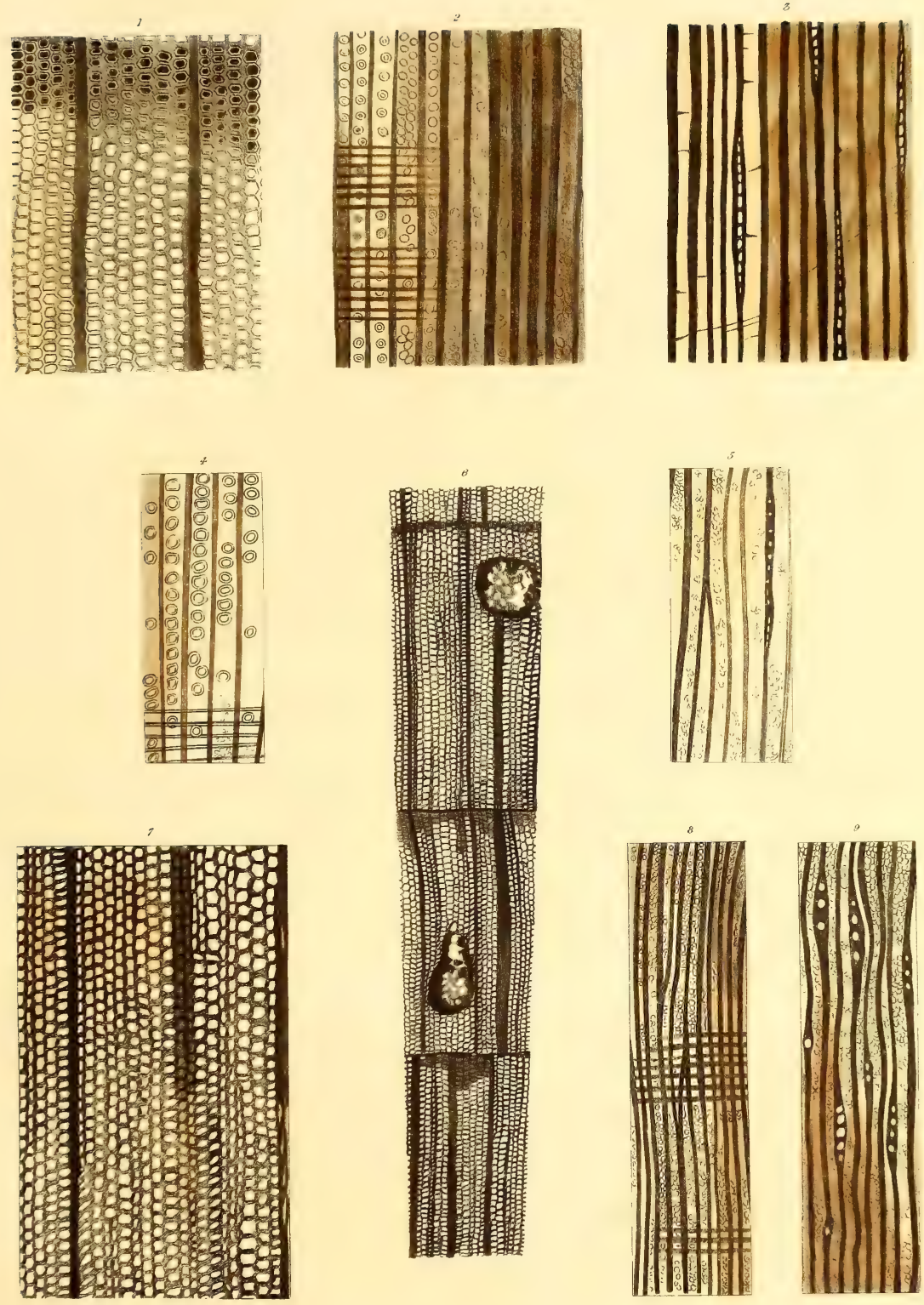


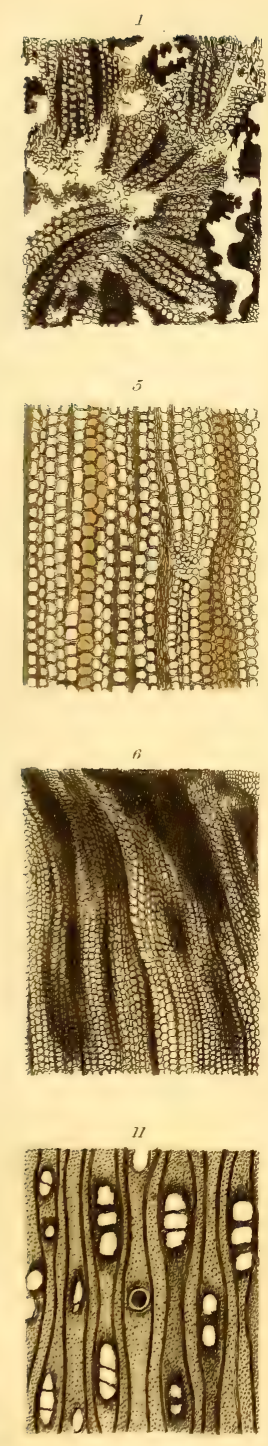
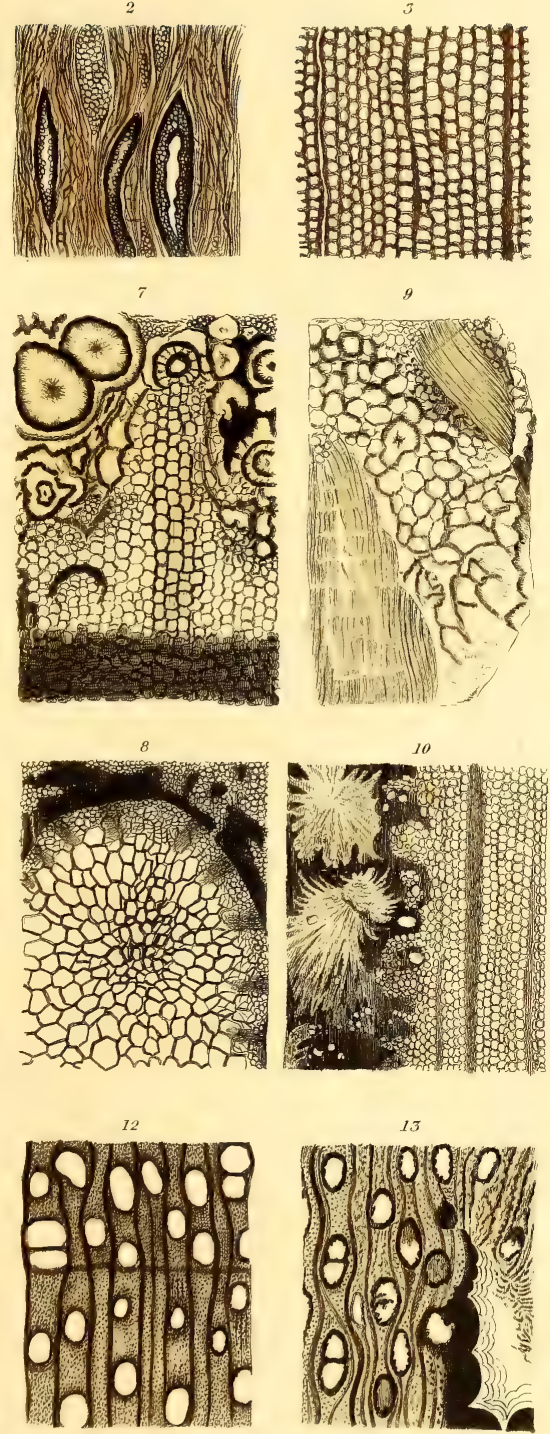

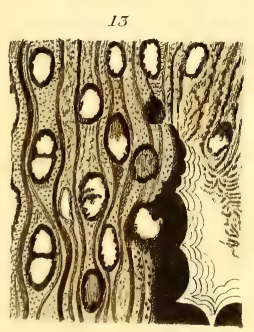

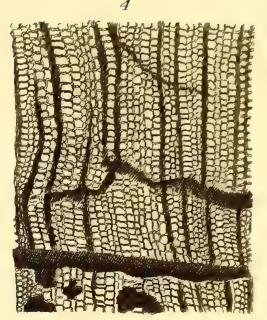
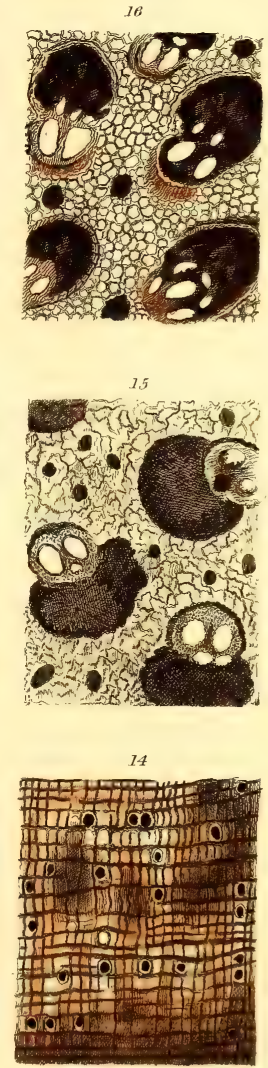











